\title{
Floresta and Bodocó Mafic-Ultramafic Complexes, western Borborema Province, Brazil: Geochemical and isotope constraints for evolution of a Neoproterozoic arc environment and retro-eclogitic hosted Ti-mineralization
}

\author{
Geysson de Almeida Lages ${ }^{\mathrm{a}, \mathrm{b}, *}$, Elton Luiz Dantas ${ }^{\mathrm{a}}$ \\ a IG - Geoscience Institute, University of Brasilia, Brasilia, DF, Brazil \\ ${ }^{\mathrm{b}}$ CPRM - Geological Survey of Brazil, Recife, PE, Brazil
}

\section{A R T I C L E I N F O}

Article history:

Received 5 August 2015

Revised 14 April 2016

Accepted 27 April 2016

Available online 04 May 2016

\section{Keywords:}

Arc cumulate rock

Supra-subduction zone

Borborema Province

\begin{abstract}
A B S T R A C T
The retrograde high-pressure metamorphosed Floresta and Bodocó mafic-ultramafic complexes (FMUC and BMUC, respectively) occur as clusters of small bodies, lenses and boudins with close association with granitic, gneissic rocks and metasediments in the southern limits of the Alto Pajeú and Piancó-Alto Brígida domains, Borborema Province, northeast Brazil. Ultramafic lithologies including metadunites, olivine cumulate rocks, metapyroxenites, chromitites and massive ilmenomagnetitites showing evidence of cumulus textures and mafic members include garnet amphibolites and coarse metahornblendites. BMUC rocks include $\mathrm{Cr}-\mathrm{Fe}-\mathrm{Ti}$ chromitites in the Fazenda Esperança deposit, and FMUC rocks show important Fe-Ti-V economic mineralization in the mines of the Serrote das Pedras Pretas and Lagoa dos Angicos and the Riacho da Posse deposit in development (54 Mt @13\% Ti). The whole-rock and mineral geochemistry of these complexes are akin to arc cumulate rocks, particularly Alaskan-type complexes, which are widely considered to have formed above subduction zones.

A coarse metahornblendite from the Serrote das Pedras Pretas mine was dated by $\mathrm{U}-\mathrm{Pb}$ zircon through laser ablation-multicollector-inductively coupled plasma-mass spectrometry (LA-MC-ICP-MS). Information obtained from the cores of igneous zircons represent an upper intercept age of crystallization at $1024 \pm 18$ Ma with 4.2 mean square weighted deviation (MSWD), whereas zircon exhibiting coarse rims with low Th/U at $0.008-0.038$ have concordia ages of $685 \pm 17$ and $625 \pm 6 \mathrm{Ma}$. According to their zircon textures, these ages may be representative of a high-grade eclogitic or progressive granulitic/ retro-eclogitic stage during the Pan-African-Brasiliano event. Additionally, the age of the igneous protolith, $1028 \pm 63 \mathrm{Ma}$, is well marked by a Sm-Nd isochron based on 12 samples.

Positive $\varepsilon \mathrm{Nd}(t)$ values between 0.01 and 4.84 suggest a depleted mantle or a source close to the chondritic reservoir for the mafic-ultramafic bodies studied. The $\mathrm{T}_{\mathrm{DM}}$ model ages between 1.1 and 1.6 Ga are consistent with a juvenile Mesoproterozoic source or mixing between Paleoproterozoic and Neoproterozoic sources. The dispersion of initial ratios of ${ }^{87} \mathrm{Sr} /{ }^{86} \mathrm{Sr}$ at $0.7016-0.7090$ and the high fractionation of light rare earth elements (LREE) relative to heavy rare earth elements (HREE) suggest a depleted mantle source metasomatized by subduction-related melts/fluids.

The mafic-ultramafic complexes, volcanic and sedimentary rocks, and some granitic intrusions with post-collisional signature after $975 \mathrm{Ma}$ constitute a proto to marginal arc-back-arc basin system that evolved between 1025 and 975 Ma. However, FMUC and BMUC which are currently arc cumulate rocks were originally picrite melts in a suprasubduction ophiolite zone.

The economic deposits of Fe-Ti associated with retro-eclogitic and ultramafic members of the FMUC and enclosed within the late Ediacaran granite can be linked in part by early accumulation under magmatic conditions, secondary enrichment of rutile up to $12 \%$ in the high-pressure (HP) stage, and hydrothermal interactions during granite emplacement.
\end{abstract}

(c) 2016 Elsevier B.V. All rights reserved.

\footnotetext{
* Corresponding author at: CPRM - Geological Survey of Brazil, Av. Sul, 2291, Recife, PE 50770-011, Brazil.

E-mail address: geysson.lages@cprm.gov.br (G.A. Lages).
} 


\section{Introduction}

Tectonic settings involving compressional and extensional environments and crustal evolution of mafic-ultramafic rock assemblages in orogenic belts can be reliably modeled by their petrogenetic and geochemical characterization (Coleman, 1971; Gass, 1980; Moores, 1982; Dilek, 2003; Dilek and Robinson, 2003; Eyuboglu et al., 2010, 2011; Su et al., 2013). During the subduction process, the oceanic floor is usually destroyed. However, some fragments of the ancient oceanic crust may be preserved as mafic-ultramafic ophiolite suites (Gass, 1968, 1980; Coleman, 1971; Moores, 1982; Dilek, 2003; Dilek and Robinson, 2003; Eyuboglu et al., 2010, 2011; Su et al., 2013). Furthermore, steadily increasing numbers of ultramafic-mafic complexes associated with orogenic belts have been attributed to intrusions into the continental basement or ancient arc systems (Irvine, 1974; Pearce et al., 1984; Himmelberg and Loney, 1995; Eyuboglu et al., 2010, 2011).

Among these types of intrusions, Uralian-Alaskan-type ultramafic-mafic complexes are examples of island arc magmatism or shallow crustal-level in situ intrusions into continental basement (Irvine, 1974; Johan, 2002; Pettigrew and Hattori, 2006; Thakurta et al., 2008; Ripley, 2009; Eyuboglu et al., 2010, 2011; Su et al., 2013). Such intrusions can be attributed to arc magma spreading center or arc-root complexes (Irvine, 1974; Taylor, 1967; Brügmann et al., 1997; Debari and Coleman, 1989; Ishiwatari and Ichiyama, 2004; Farahat and Helmy, 2006; Zaccarini et al., 2008) related to the subduction environment and arc accretion (Taylor, 1967; Irvine, 1974; Pettigrew and Hattori, 2006; Su et al., 2012) and their consistent cumulate rocks can be formed as part of oceanic or continental arcs (Loucks, 1990; Eyuboglu et al., 2010).

These complexes are considered to be classic ophiolitic suites, which are mostly associated with ancient suture zones and have evolved under diverse geological environments (Yellappa et al., 2014). The most favorable of these is the Suprasubduction Zone (SSZ) environment (Irvine, 1974; Farahat and Helmy, 2006; Tian et al., 2011), which englobes the arc roots (e.g., Alaskan type) and includes the spreading centers related to the other parts of the arc environment development such as proto-arcs, fore-arcs and back-arcs formed during different stages of arc evolution (Shervais, 1982; Kusky et al., 2007; Dijkstra et al., 2006). The Uralian-Alaskan-type intrusions occur as small-scale plutons commonly characterized by concentric zoning. From core to rims, the lithologies are dunites and chromitites, wehrlites, clinopyroxenites, hornblendites, and gabbros, all showing characteristic cumulate textures (Taylor, 1967; Irvine, 1974; Himmelberg and Loney, 1995; Johan, 2002; Farahat and Helmy, 2006; Chen et al., 2009; Tian et al., 2011; Su et al., 2012). This zonal structure, however, can be discontinuous, incomplete, asymmetrical, and even reversed (Himmelberg and Loney, 1995; Eyuboglu et al., 2010, 2011). Nevertheless, many of these sequences consist of a single rock type, with hornblendite and peridotite the most abundant and clinopyroxenite or gabbro occurring in subordinate proportions (Eyuboglu et al., 2011; Himmelberg and Loney, 1995; Irvine, 1974). In most cases, the intrusions occur as kilometerscale linear belts (Krause et al., 2007).

In addition, similar small intrusions within orogenic belts hosting $\mathrm{Ni}-\mathrm{Cu}$ sulfide and $\mathrm{Ti}-\mathrm{Fe}$ oxide deposits have been correlated with a post-orogenic extensional setting (Zhang et al., 2009, 2011; Song et al., 2011; Gao et al., 2012; Su et al., 2013; Xie et al., 2014).

Occasional $\mathrm{Ti}$ deposits have been described as eclogite-type with a ferrogabbroic parental magma, whereas the most common economic mineral in such association is rutile rather than ilmenite (Force, 1991). Because Ti is known to be fairly immobile during chemical alteration and metamorphism, the parent rock must have had sufficient Ti to qualify as a mineral resource (Force, 1991).

Several mafic-ultramafic complexes occur as discontinuous bodies in the Alto Pajeú and Piancó/Alto Brígida domains in the western part of the Zona Transversal Subprovince, Borborema Province; these complexes are host rocks of economic $\mathrm{Fe}-\mathrm{Ti}-\mathrm{V} \pm \mathrm{Cu}$ deposits (Floresta/PE). Atypical occurrences of $\mathrm{Cr}-\mathrm{Ti}-\mathrm{Fe}$ spinels (Bodocó/PE) may mark an important tectonic association related to a subduction zone. Beurlen et al. (1992) presented evidence that these rocks underwent high-pressure metamorphic stages. However, this contention needs to be substantiated by further geochronological, geochemical, and isotopic data. In this paper, we present whole-rock geochemical and laser ablation-multicollec tor-inductively coupled plasma-mass spectrometry (LA-MC-ICPMS) $\mathrm{U}-\mathrm{Pb}, \mathrm{Sr}-\mathrm{Nd}$ isotopic data of the Floresta Mafic-Ultramafic Complex (FMUC), Serrote das Pedras Pretas Suite. In addition, we reevaluate the published data regarding FMUC-Riacho da Posse deposit and the Bodocó Mafic-Ultramafic Complex (BMUC)Fazenda Esperança. This paper aims to utilize the geochemistry of FMUC and BMUC to infer the eclogite protolith. Our findings provide clues for understanding the tectonic architecture and conditions of Fe-Ti enrichment in some of the economically significant bodies.

\section{Geologic setting and previous studies}

The Borborema Province (Almeida et al., 1981) can be traced to the amalgamation of the São Francisco-Congo, São Luís, West Africa, and Amazonian cratons during the Gondwana assembly, known in this region as the Brasiliano Orogeny. It has a complex tectonic-magmatic framework marked by several episodes of magmatism (Almeida et al., 1981; Ferreira et al., 1998; Santos and Medeiros, 1999; Neves et al., 2000; Nascimento et al., 2000, 2008; Guimarães et al., 2004; Van Schmus et al., 2011). Several continental-scale high-temperature shear zones allow discrimination of this province into several tectonic domains (Fig. 1a; Caby et al., 1991; Corsini et al., 1991; Jardim de Sá, 1994; Vauchez et al., 1995). This structural mosaic has been described in terms of origin and evolution and is reflected in a variety of proposed nomenclatures (e.g., Brito Neves, 1983; Santos and Brito Neves, 1984; Jardim de Sá et al., 1992; Jardim de Sá, 1994; Van Schmus et al., 1995; Santos et al., 1999; Santos and Medeiros, 1999; Brito Neves et al., 2000, 2001a,b, 2005; Oliveira, 2008).

The study area is situated in the western portion of the Zona Transversal or Central Subprovince (Fig. 1a and b), which is limited by the large east-west (E-W) trending Patos and Pernambuco transcurrent shear zones and various northeast-southwest (NESW)-trending crustal segments.

The FMUC, Serrote das Pedras Pretas suite (Fig. 2), occurs as clusters of small mafic to ultramafic rock sequences that are commonly mineralized by massive $\mathrm{Fe}-\mathrm{Ti}-\mathrm{V}$ oxides and minor primary disseminated $\mathrm{Ni}-\mathrm{Cu}$ sulfides. Most of the bodies are subrounded and are less than $1.5 \mathrm{~km}^{2}$ in diameter. Folded lenses extend beyond the subrounded "intrusions," which are currently xenoliths. Mineralization is present in ultramafic members, as indicated by intercumulus/cumulus textures in pyroxenites and olivine cumulates (Beurlen et al., 1992). FMUC forms a part of the Alto Pajeú Domain, which consists primarily of rocks generated during the Tonian Cariris Velhos event (Brito Neves et al., 1995; Santos, 1995; Santos et al., 1999, 2010). The FMUC crops out in metavolcanic-sedimen tary sequences, metagraywackes, and mica schists known as São Caetano Complex. Its minimum age has been constrained at $995 \pm 8 \mathrm{Ma}$ (Santos et al., 2010) on the basis of U-Pb zircon data of an intrusive metatuff situated north of Floresta. Other regional ages for volcanogenic and supracrustal rocks in the Alto Pajeú 

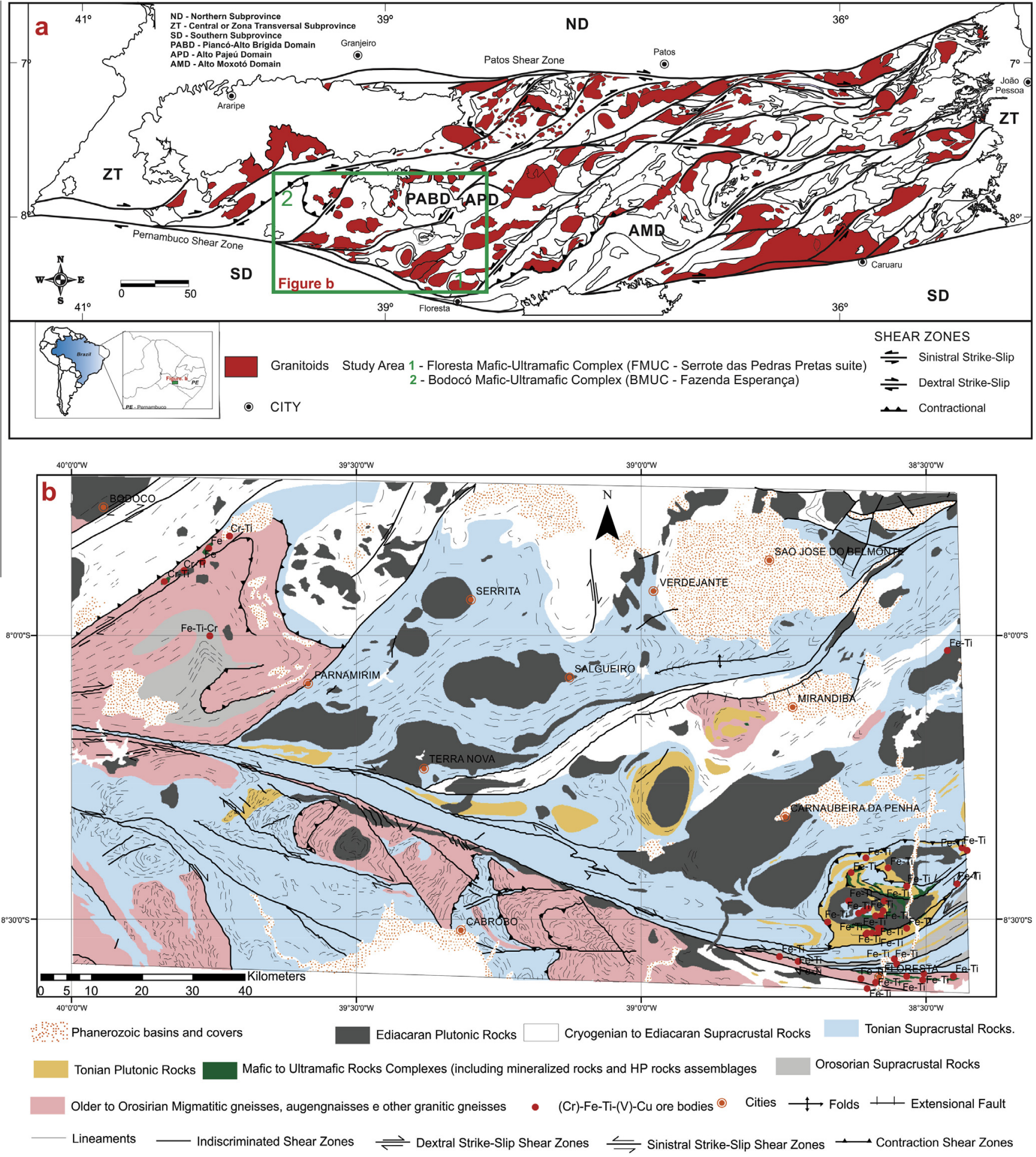

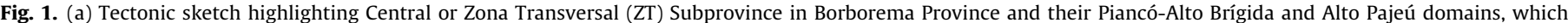

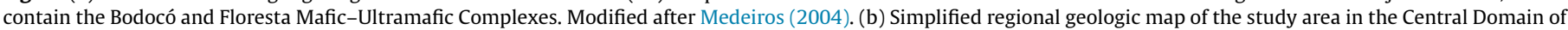
Borborema Province showing distribution of the mafic-ultramafic complexes. Modified after Gomes and Santos (2001).

Domain, at 995-965 Ma also fall within the same age bracket (Santos et al., 2010). The oldest ages found thus far are in the eastern part of the Alto Pajeú Domain and include the Sítio do Icó fine-grained gneiss, which is a subvolcanic rock with andesitic character at $1005 \pm 5 \mathrm{Ma}$ (Lages et al., 2014; Guimarães et al., 2015) and a gneiss at $1037 \pm 30$ Ma (Van Schmus et al., 1995). Detrital sedimentation determined in younger zircon by Sensitive High
Resolution Ion Microprobe (SHRIMP) at $932 \pm 12$ Ma (Van Schmus et al., 2011) indicates an extensional setting after the Cariris Velhos magmatism. Almost all of the metaplutonic rocks show more precise results falling in the interval of 960-925 Ma, which is generally younger than the ages of the metavolcanic rocks (Brito Neves et al., 1995; Kozuch, 2003; Santos et al., 2010; Guimarães et al., 2015). The tectonic setting of the Tonian granitoids is still 


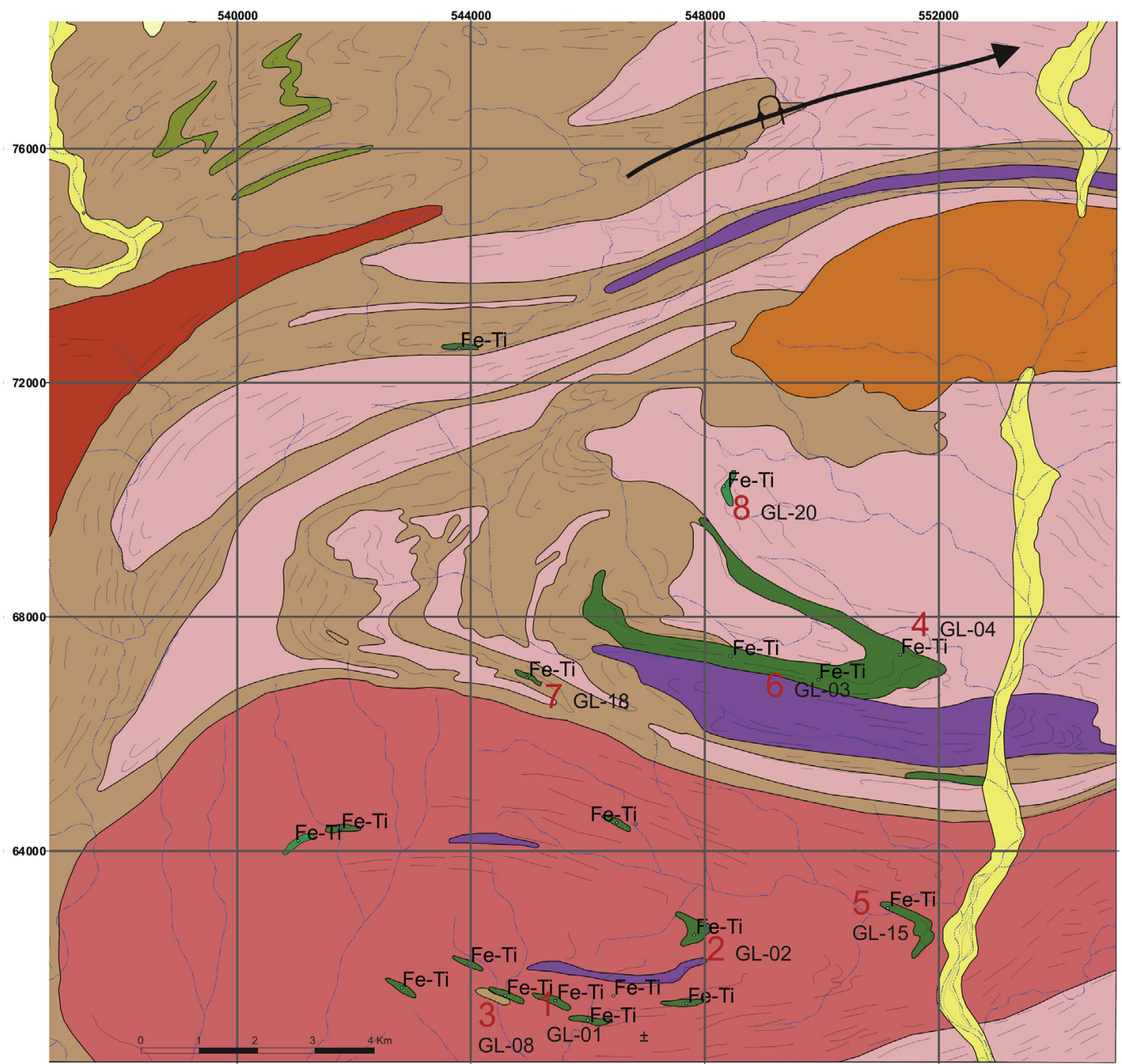

Covers

Serra do Man - Alkali feldspar granites/syenites

São João Grande - Hornblende e/or biotite quartz-syenites, syenites, quartz-monzonites and fine-grained to porphyritic alkalifeldspargranites. $592 \mathrm{Ma} \mathrm{U}-\mathrm{Pb}$ (Santos 1995)
Riacho do Icó Suite: Coarse-grained to porphyritic hornblende-biotite granodiorites, monzogranites, quartz-diorites and quartzmonzonites. 608 Ma U-Pb SHRIMP(Santos et al 2014)

\section{Cariri Velhos Event}

Floresta Mafic-Ultramafic Complex (Serrote das Pedras Pretas Suite) - Metapyroxenites, olivine-cumulates, garnet amphibolites, coarse hornblendites, massive ilmenomagnetitites $\left(>40 \% \mathrm{wt} \mathrm{TiO}_{2}\right)$, veinlets of serpentinites.

São Caetano Complex: (Garnet) muscovitebiotite gneisses, sometimes migmatized, Schists, marbles, quartzites and metavolcanoclastics rocks. $\sim 1089 \pm 143 \mathrm{Ma} \mathrm{U}-\mathrm{Pb}$ TIMS -

$-995 \mathrm{Ma}$ (Metatuff) (Santos 1995)
Riacho do Forno: Orthogneisses and migmatites
with granodioritic to monzogranitic composition. $\sim 995 \mathrm{Ma}$ (Brasilino et al 2014)

Rock sampling sites: 1 Lagoa dos Angicos (GL-01)

C h e m i c a I a n d 2 Serrote das Pedras Pretas (GL-02) isotopic analyses 3 Riacho da Posse (GL-08) 4 Riacho do Tapuio (GL-04)

5 Fazenda Exú (GL-15)

6 Caraibeiras (GL-03) 7 Tapuio (GL-18)

8 Cachoeira Grande (GL-20)
Recanto - augengneissess. Tonian ages.

$\sim 975$ Ma (Kozuch 2003; Santos et al 2010)

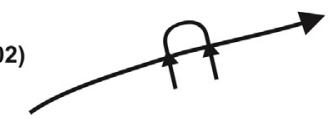

Inverse synform

Fig. 2. Simplified geological map of Floresta Mafic-Ultramafic Complex (FMUC) and rock sampling positions. Modified after Brasilino et al. (2014),

under debate; they are related to either a continental margin magmatic arc with possible back-arc association (Brito Neves et al., 2000; Santos et al., 2010; Oliveira et al., 2010; Kozuch, 2003; de Caxito et al., 2014a; Van schmus et al., 2011) or to an extensionrelated setting with generation of A-type granites (Guimarães et al., 2012, 2015; Neves, 2003).

Despite this discussion, however, the major economic deposits of FMUC include the Riacho do Icó Suite as a wall rock and large xenoliths as floats within it. The Riacho do Icó Suite is composed of a composite felsic intrusion with compositions ranging from quartz monzodiorite and granodiorite to monzogranite. $\mathrm{U}-\mathrm{Pb}$ SHRIMP zircon analysis yielded a crystallization age of $608 \pm 5$ Ma (Santos et al., 2014).

The BMUC, Fazenda Esperança type (Fig. 3), was emplaced within the Piancó-Alto Brígida basement. The former is known as the Salgueiro-Cachoeirinha belt, which is comprised of several 


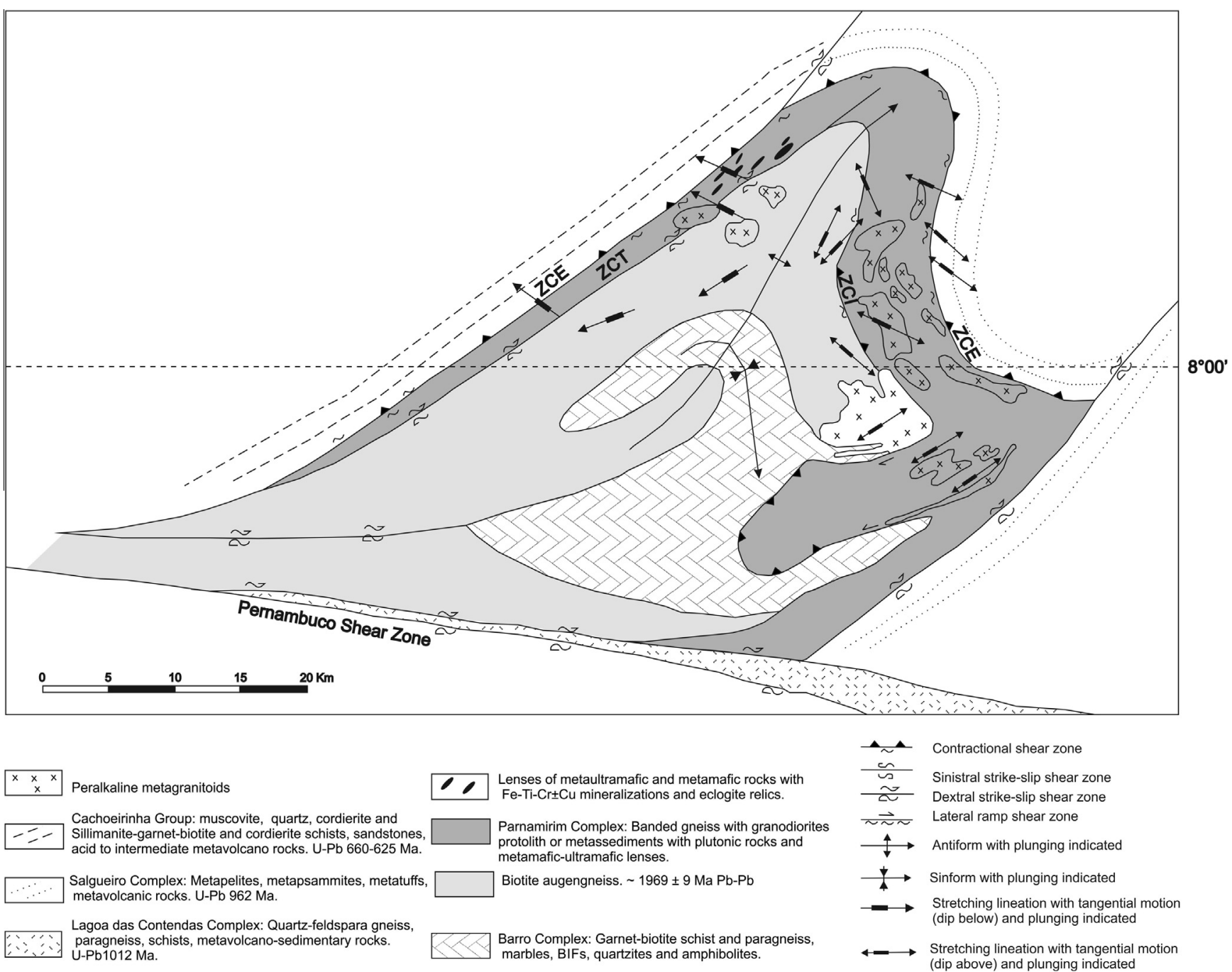

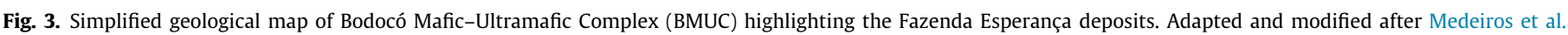
(1993).

lensoid mafic-ultramafic bodies occurring peripheral to the NW limb of a regional anticlinal fold structure close to the tectonic contact between Neoproterozoic low to medium-grade metamorphic supracrustal rocks of the Salgueiro Complex and the Cachoeirinha Group. The core of the anticlinal structure, known as the Icaiçara fragment (Medeiros et al., 1993), is a composite granitoid (granite gneiss, migmatitic to banded gneiss) that hosts the BMUC and a psammitic-pelitic-carbonate sequence (staurolite-kyanite bearing in places) related to the Barro Complex (Medeiros et al., 1993). A single crystal zircon $\mathrm{Pb}-\mathrm{Pb}$ age of $1969 \pm 9$ Ma was determined from an augen gneiss that crosscuts the migmatitic gneiss, which constrains the minimum age of the rocks in the core of the anticline (Medeiros et al., 1993). A detailed petrographic analysis of two garnet-rich gabbroic members of the BMUC was conducted to ascertain their eclogitic affinities (Beurlen and Villarroel, 1990; Beurlen, 1988; Beurlen et al., 1992).

A metarhyodacitic sheet interspersed within a biotite schist collected near the homonymous area has been dated at $962 \mathrm{Ma}$, which constrains the age of the Salgueiro Complex (Brito and Cruz, 2009). The Cryogenian-Ediacaran age of 650-625 Ma $(\mathrm{U}-\mathrm{Pb})$ for the Cachoeirinha Group is constrained by zircons from the rhyolite (Van Schmus et al., 1995; Kozuch, 2003; Medeiros, 2004), and recent SHRIMP U-Pb data in detrital zircons reinforced an age younger than $630 \mathrm{Ma}$ (Van Schmus et al., 2011).

\section{Analytical methods}

The U-Pb, Sm-Nd, Sr-Sr, and microprobe analyses were performed at the University of Brasilia (UnB) facilities, Brazil. Zircon, garnet, pyroxenes, and amphiboles were selectively liberated by using high-voltage pulsed power discharges provided by power fragmentation equipment (SELFRAG, Kerzers Switzerland). The concentrations of heavy minerals were then processed by using a magnetic separator (S.G. Frantz, New Jersey, USA).

For $\mathrm{U}-\mathrm{Pb}$ geochronological analysis, zircon grains were handpicked and mounted on an adhesive tape, enclosed in epoxy resin, and polished to approximately half of their original thicknesses. $\mathrm{U}-\mathrm{Pb}$ analysis was performed on a Mass Spectrometer MultiCollector (Finnigan Neptune, Thermo Scientific, NYSE:TMO) with ICP following the methods described by Bühn et al. (2009). For data reduction and age calculations, the programs PBDAT (Ludwig, 1993) and ISOPLOT-Ex (Ludwig, 2001) were used. Isotopic errors were in the range of $1 \sigma$.

Sm-Nd analyses were performed following the method described by Gióia and Pimentel (2000). Whole rock powders and leached minerals were mixed with an ${ }^{149} \mathrm{Sm}-{ }^{150} \mathrm{Nd}$ spike solution and dissolved in Savillex capsules. The Sm and Nd extraction of whole-rock samples followed conventional cation exchange techniques using Teflon columns containing LN-Spec resin (diethylhexyl phosphoric acid; HDEHP) supported on 
polytetrafluoroethylene (PTFE) powder. Sm and Nd samples were loaded on a Re double-filament evaporation assembly, and the isotopic measurements were conducted by MS (Triton Plus, Thermo Scientific). Uncertainties of $\mathrm{Sm} / \mathrm{Nd}$ and ${ }^{143} \mathrm{Nd} /{ }^{144} \mathrm{Nd}$ were better than $\pm 0.4 \%(1 \sigma)$ and $\pm 0.005 \%(1 \sigma)$, respectively, based on repeated analyses of international rock standards Basalt, Hawaiian Volcanic Observatory (BHVO-1) and Basalt, Columbia River (BCR-1). ${ }^{143} \mathrm{Nd} /{ }^{144} \mathrm{Nd}$ was normalized to ${ }^{146} \mathrm{Nd} /{ }^{144} \mathrm{Nd}$ of 0.7219 , and the decay constant used was $6.54 \times 10^{-12}$. $\mathrm{T}_{\mathrm{DM}}$ model ages were calculated by using the procedure given in DePaolo (1981). The opensource GcdKit isotopic plug-in (Janoušek et al., 2006) was used to help generate $\mathrm{Nd}$ evolution curves and other graphs.

The $\mathrm{Sr}$ isotopic compositions were obtained by using a MS (Triton Plus, Thermo Scientific). The total analytical blank for $\mathrm{Sr}$ remained close to $0.2 \mathrm{ng}$. The $2 \sigma$ uncertainties for the ${ }^{87} \mathrm{Sr} /{ }^{86} \mathrm{Sr}$ were less than $0.01 \%$.

Electron microprobe analysis was performed by using a SuperProbe Electron Probe Microanalyzer (EPMA; JXA-8230, Jeol, Japan) with five wavelength dispersive spectrometers (WDS) coupled with one energy dispersive spectrometer (EDS). The available analyzer crystals (TAPJ, LIF, LIFH, PETJ, PETH, LDE1, and LDE2) allowed all chemical elements with atomic numbers greater than 4 following certain routine conditions such as (a) beam current of $10 \mathrm{nA}$; (b) beam diameter of $3 \mu$, and (c) accelerating voltage of $15 \mathrm{kV}$. The pyroxene group was recalculated by using the Visual Basic ${ }^{\circledR}$ program Winpyrox (Yavuz, 2013). The amphibole group was recalculated with the aid of an updated PROBE-AMPH 3.0 Excel spreadsheet (Tindle and Webb, 1994). Recalculations on coexistent pairs of magnetite and ilmenite including temperature $\left(\mathrm{T} ;{ }^{\circ} \mathrm{C}\right)$ and $\log _{10} \mathrm{fO}_{2}$ were aided by the ILMAT Excel spreadsheet (Lepage, 2003).

Whole-rock samples were analyzed at Acme Analytical Laboratories Ltd. (Canada). A small portion of the analyses was also conducted at SGS Geosol Ltd. (Brazil) for rock samples started at AM abbrev. The opening method used was the $\mathrm{LiBO}_{2}$ melt and multiacid solution. The methods of multi-element analysis passed through ICP-MS, ICP-atomic emission spectroscopy (AES), and $\mathrm{X}$-ray fluorescence according to elemental groups. The latest version of GCDkit 3.0 assisted in data interpretation.

Back-scattered images and EDS spots analyses were obtained by using scanning electron microscopy (SEM)/EDS (Quanta 450, FEI, Oregon, USA) coupled with $\sim 10 \mathrm{~mm}$ WD and $20 \mathrm{kV}$ of acceleration voltage.

\section{Results}

\subsection{Mineralogy and petrography}

Twenty occurrences of Fe-Ti mineralization and ultramaficmafic rocks in the FMUC were reviewed, and eigth were selected for a more detailed petrographic, microprobe, geochemical, and isotopic analyses (see Fig. 2). Rock samples from freshly exposed mining pits such as Serrote das Pedras Pretas (GL-02), Riacho da Posse (GL-08), Lagoa dos Angicos (GL-01), and Fazenda Exú (GL-15); prospecting trenches and material accessed after the installation of a high-voltage transmission line over Riacho do Tapuio (GL-04) provided material suitable for chemical, geochronological, and isotopic analyses as well as documentation of geological relationships.

Primary and high-pressure mineral assemblage, and retrometamorphic minerals observed in thin sections from the FMUC are given in Inline Supplementary Fig. S1.

\subsubsection{Metadunites and olivine cumulates}

Metadunite and olivine cumulates commonly occur as mineralized olivine cumulates with net ore textured intergranular ilmenite and magnetite (Fig. $4 \mathrm{a}$ and f). Disseminated $\mathrm{Ni}-\mathrm{Cu}-\mathrm{Fe}$ sulfides are interstitial and occur together with Fe-Ti oxides and silicates. Serpentinized olivine in the mineralized dunite is altered to chlorite, serpentine, and crystals of an acicular amphibole (cummingtonite or anthophyllite), whereas clinopyroxenes are replaced by tremolite. A massive dark-green, strongly serpentinized metadunite (Fig. 4b) occurs in the Serrote das Pedras Pretas mine. In compacted dunites, the olivines are pseudomorphs generated by their breakdown leaving serpentinite/chlorite, iddingsite, and a corona texture of magnetite. Thick, massive ore bands of ilmenomagnetitites of up to $3 \mathrm{~m}$ (Fig. 4c) encompass a layer concordant with these ultramafic members, and thin discordant veins crosscut them.

\subsubsection{Metaclinopyroxenites}

Clinopyroxenites, tremolitites, and cpx-tremolite-chlorite schists are closely associated with olivine cumulates and preserve Fe-Ti-V net textured mineralization. The gradation between wehrlites to pyroxenites, best observed in the Riacho Tapuio occurrence, consists of (olivine) clinopyroxene-tremolite-chlorite schists with pyroxenes and rare cordierite. Clinopyroxenites and wehrlites are mainly present with garnet amphibolites and metahornblendites but are also be observed in fine-grained metapyroxenites. We suppose that some metaultramafic schists surrounding dunites are products of recrystallization of metawehrlites and metapyroxenites showing cumulus clinopyroxenes (augite and diopsides) mostly altered to actinolite, tremolite, or cordierite from altered serpentines (Fig. 4e).

\subsubsection{Garnet amphibolite}

The garnetiferous amphibolites contain up to 50 garnet modal, reaching up to $1.5 \mathrm{~cm}$ in an amphibole matrix (Fig. 4d). Some high modal $(>50 \%)$ terms of elongated garnets with large amounts of Fe-Ti oxides can also be considered as garnetites. Porphyroblastic garnets always show intense fracturing and the presence of amphibole, rutile, plagioclase, clinozoisite, and quartz occurring as snowball texture inclusions. The most voluminous amphibole is slightly oriented, with light yellow-greenish pleochroism compatible with a hornblende composition. Other variations include tremolite/actinolite and sodic amphiboles with bluish and purple tones.

Symplectites are formed around garnets and are composed of intergrowths of amphibole, rutile, clinozoisite, and scarce small grains of plagioclase (Fig. $4 \mathrm{~d}$ and i). Coronitic olivine (Fig. 4g) occurs in some members and indicate olivine gabbro or even troctolite protoliths.

\subsubsection{Coarse metahornblendite}

Metahornblendites are usually associated with garnet amphibolites (Fig. 4d). They appear as idiomorphic crystals of coarse hornblende with variable pleochroism and accessory minerals of more than $4 \%$ such as idiomorphic rutile parallel to elongated crystal faces (Fig. 4h), titanite, magnetite, and interstitial fine-grained albite plagioclase.

\subsubsection{Ilmenomagnetitite or massive ore shoot}

Three types of massive ilmenite-magnetite bands occur, particularly in thick lenses concordant to the host rocks (Fig. 4c) and centimeter-sized discordant veins commonly associated with cross-fiber veins of serpentinites crosscutting the third type, which consists of olivine \pm pyroxene \pm tremolite \pm chlorite cumulates surrounded by (inter)cumulus Fe-Ti-V oxides. The amounts of disseminated mineral assemblages composed of rutile + sphene or pyrrhotite + chalcopyrite + pentlandite blebs can also be considered as an accessory mineralogy.

The interstitial xenomorphic ilmenite-magnetite ores with respect to silicates suggest a cumulatic origin for the euhedral pyroxene/olivine formation of a network texture. Massive coarse-grained ores form polygonal crystals of $\mathrm{V}$-magnetite and 

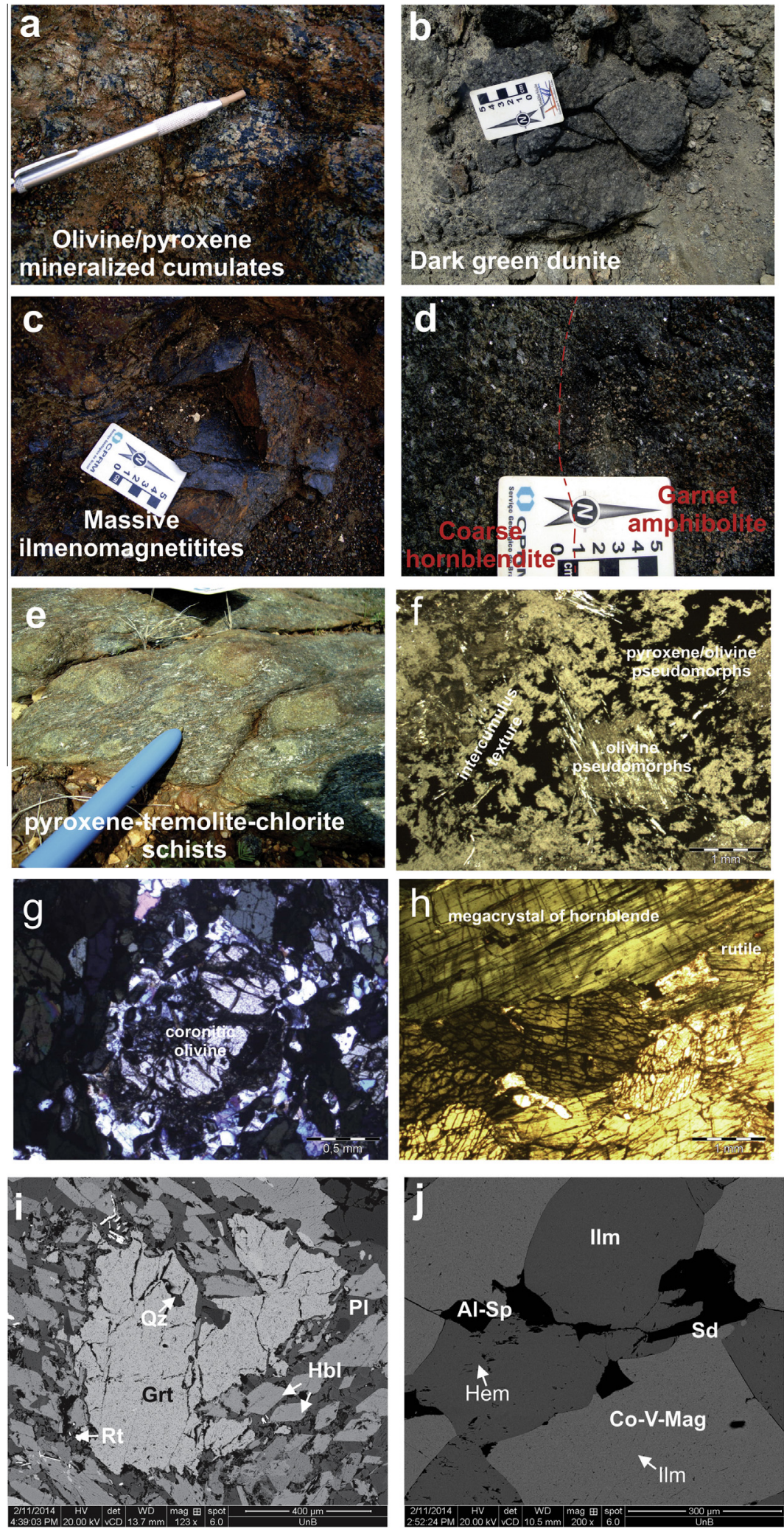

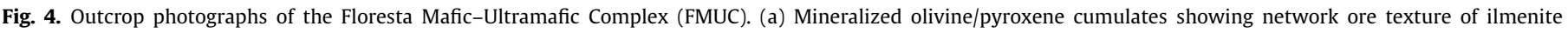

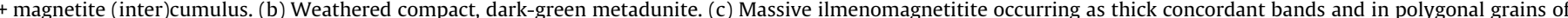

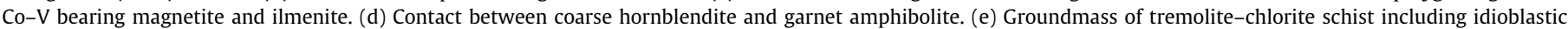

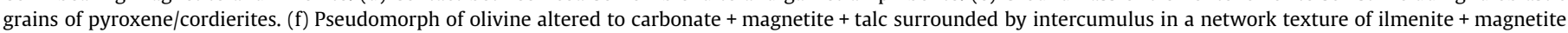

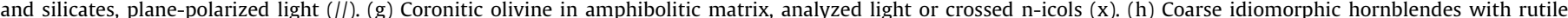

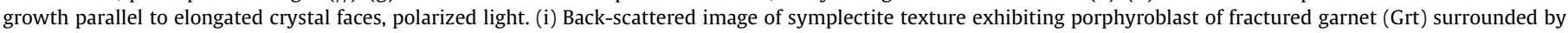

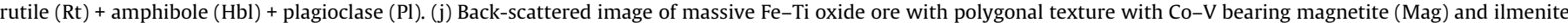

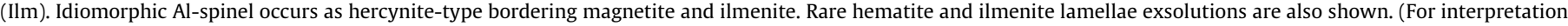
of the references to colour in this figure legend, the reader is referred to the web version of this article.) 
ilmenite intergrowths (Fig. 4c) showing complete oxidation exsolution where lamellae of ilmenite is rare in magnetite and hematite, and magnetite is virtually absent in ilmenite (Fig. $4 \mathrm{j}$ ). The magnetite and ilmenite have approximately the same proportions in coarse massive ores. Idiomorphic grains of hercynite are in contact with ilmenites and magnetites, suggesting an exsolution origin. Titanite, rutile, siderite, sulfides, and silicate gangue are subordinate minerals.

\subsection{Mineral chemistry}

Three thin sections from the FMUC were selected to perform electron microprobe analysis of the following minerals: Al-spinel, magnetite, and ilmenite in a massive ilmenite-magnetite ore band from Fazenda Exú (GL-15 UTM 551130; 9063033); and amphiboles, garnet, plagioclase, epidote, titanite, and rutile in metahornbledite and garnet amphibolite from Riacho do Tapuio (GL-04A and GL-04B UTM 551344; 9067350).

In addition, we recalculated all Cr-spinels, pyroxenes, and amphiboles from Fazenda Esperança (BMUC) and amphiboles from the Riacho da Posse deposit (FMUC) reported by Beurlen (1988). The results are presented here as appendices.

\subsubsection{Spinels, magnetite, and ilmenite}

Al-spinel, commonly hercynite, is present as an accessory phase in the massive ilmenite-magnetite ore bands from Floresta/PE and occurs at the boundary between ilmenite and vanadiferous magnetite. It is characterized by low $\mathrm{Cr}_{2} \mathrm{O}_{3}$ at $0.2-0.39$ wt.\% and, higher $\mathrm{Al}_{2} \mathrm{O}_{3}$ at $54.9-57.4$ wt.\%, $\mathrm{FeO}$ at $19.64-22.24 \mathrm{wt} . \%, \mathrm{TiO}_{2}$ at 5.5-7.4 wt.\%, and $\mathrm{V}_{2} \mathrm{O}_{3}$ at $0.32-0.51$ wt.\%. It exhibits a low $\mathrm{Mg \#}(100 \times$ $\left.\mathrm{Mg} /\left(\mathrm{Mg}+\mathrm{Fe}^{2+}\right)\right)$ and a $\mathrm{Cr} \#(100 \times \mathrm{Cr} /(\mathrm{Cr}+\mathrm{Al}))$ ranging between 40.7-45.7 and 0.25-0.45, respectively. (Inline Supplementary Table 1)

$\mathrm{Cr}$-spinel, commonly Fe-chromite, occurs in massive cumulate bands in Bodocó/PE (Inline Supplementary Appendix A) revealing that the Fe-chromites have lower contents of $\mathrm{Al}_{2} \mathrm{O}_{3}$ at $0.64-$ 11.96 wt.\%, and $\mathrm{MgO}$ at $0.04-8.38$ wt.\% in addition to wide ranges of $\mathrm{TiO}_{2}$ at $0.92-20.71$ wt.\%, $\mathrm{Cr}_{2} \mathrm{O}_{3}$ at $15.25-34.68$ wt.\%, and $\mathrm{FeO}$ at 31.43-65 wt.\%. Its $\mathrm{Cr} \#$ is between 48 and 97, and its $\mathrm{Mg \#}$ ranges from 0 to 52.8 .

The magnetites are vanadiferous magnetites with low $\mathrm{TiO}_{2}$ at 0.11-0.49 wt.\%. $\mathrm{Fe}_{2} \mathrm{O}_{3}^{t}$ and $\mathrm{V}_{2} \mathrm{O}_{3}$ range from 82.87 to 85.96 and 1.82 to $2.1 \mathrm{wt} . \%$., respectively, and they exhibit low contents of $\mathrm{Al}_{2} \mathrm{O}_{3}$ and $\mathrm{Cr}_{2} \mathrm{O}_{3}$ at $\sim 0.4$ and $\sim 0.35$. The mole fraction of uvölspinel ranges from 0.37 to $1.70 \%$.

The ilmenites form an equigranular mosaic with magnetite in net-texture ore bodies and massive form with $>40 \%$ of ilmenites. Their contents of $\mathrm{TiO}_{2}$ range from 48.6 to $51.5 \mathrm{wt}$.\%; $\mathrm{FeO}$ and $\mathrm{V}_{2} \mathrm{O}_{5}$ are $44.4-45.9$ wt.\%, and $0.34-0.98 \mathrm{wt} . \%$, respectively. The mole fraction of ilmenite, $>92.42 \%$, confirms the absence of exsolution.

\subsubsection{Pyroxenes}

Clinopyroxene and $\mathrm{Ca}-\mathrm{Na}$ pyroxene are from pyroxenites and porphyroclastic clinopyroxene tremolitites (Inline Supplementary Appendix B). The porphyroclastic clinopyroxene in the clinopyroxene tremolitites is mostly diopside and augite with high $\mathrm{Mg \#}$ at 88.8-99.5 and high $\mathrm{CaO}$ 21.8-24.2\%; lower contents of $\mathrm{TiO}_{2}$ at $0.00-1.32$ wt.\%, $\mathrm{Al}_{2} \mathrm{O}_{3}$ at $0.00-1.68$ wt.\%, and $\mathrm{Na}_{2} \mathrm{O}$ at $0.00-$ 0.69 wt.\%; and moderate to high $\mathrm{Cr}_{2} \mathrm{O}_{3}$ 0.23-0.54\%. The minerals in metapyroxenite show relatively low values of $\mathrm{TiO}_{2}$ at 0.0 0.14 wt.\%, $\mathrm{Al}_{2} \mathrm{O}_{3}$ at $0.83-2.09$ wt.\%, and $\mathrm{Na}_{2} \mathrm{O}$ at $0.31-0.73$ wt.\%, and high $\mathrm{CaO}$ at $24.15-25.63$ wt.\% and $\mathrm{Mg \#}$ at $91.8-100$.

In the eclogite, $\mathrm{Ca}-\mathrm{Na}$ omphacites were recognized (Appendix $\mathrm{B}$; Beurlen et al., 1992), although a single crystal of augite recorded low $\mathrm{Al}_{2} \mathrm{O}_{3}$ at 4.90 wt.\% and $\mathrm{Na}_{2} \mathrm{O}$ at $1.34 \mathrm{wt} . \%$ and high $\mathrm{MgO}$ at 14.8 wt.\%. The $\mathrm{Mg} \#$ varies between 80.45 and 95.98 . They are also characterized by relatively high $\mathrm{TiO}_{2}$ at $0.51-2.03$ wt.\% and $\mathrm{Cr}_{2} \mathrm{O}_{3}$ at $0.22-1.92$ wt.\%; low $\mathrm{Na}_{2} \mathrm{O}$ at $0.20-0.65 \mathrm{wt} . \%$; and variable amounts of $\mathrm{Al}_{2} \mathrm{O}_{3}$ at $1.60-4.97 \mathrm{wt} . \%$. Almost all spots present a core-to-rim variation in $\mathrm{SiO}_{2}$ and $\mathrm{Al}_{2} \mathrm{O}_{3}$.

\subsubsection{Amphiboles and garnets}

Hornblende group minerals (hbl) are the most abundant and exhibit a wide range of compositions in the FMUC (Inline Supplementary Table 2) and BMUC (Inline Supplementary Appendix C). Nomenclature names according to Leake et al. (1997, 2004). Secondary hbl has inherited precursory compositions of clinopyroxene occurring mainly as tremolite or actinolite in the case of eclogite and pyroxenite and is predominantly magnesium-hbl and tschermakitic hornblende. Some relics as inclusions or in snow-ball textures can be primary hbl that includes ferroan pargasite in addition to Fe-tschermakite (hornblende) and Mg-hbl. The most Mg-rich hornblendes have Mg\# $\sim 1$ (c.f. between 0.43 and 1 in amphibolites). Hornblendes have higher contents of $\mathrm{CaO}$ at 6.26-12.65, $\mathrm{Na}_{2} \mathrm{O}$ at $0.66-2.93$, and $\mathrm{MgO}$ at 6.42-20.24 and they have variable contents of $\mathrm{TiO}_{2}$ and $\mathrm{Al}_{2} \mathrm{O}_{3}$ with a positive correlation in eclogite symplectites in addition to $\mathrm{SiO}_{2}$. Fe-tschermakitic hornblende and (ferri)-barroisite (Na-Ca group) were identified in symplectites from eclogite (BMUC; BO-436) and grains from garnet-amphibolite (FMUC; RP-614).

Cr-poor granoblastic garnets from a garnet amphibolite (Inline Supplementary Table 2) in the FMUC have a composition of almandine $_{52.09-55.24}$, pyrope $10.69-14.27$, grossular $26.73-29.91$, and sperssatite $_{2.83-7.58}$. Millimeter-scale xenoblastic terms in symplectite intergrowths show depletion in the mole fraction of pyrope ${ }_{7.65}$ with incipient replacement of $\mathrm{Mg}$ by $\mathrm{Mn}$. These garnets have ubiquitous inclusions of quartz, rutile, and amphibole.

\subsubsection{Plagioclase, epidote, titanite, and rutile}

Plagioclase (Inline Supplementary Table 3) is absent in the dunite/olivine cumulates, coarse hornblendites, massive and nettextured ore bodies and is present only as part of the symplectites in the garnet amphibolite of the FMUC samples. An individual small grain and a symplectite intergrowth have a similar An content of $\sim 40$, which is close to the andesine composition. A single grain found in a metahornblendite sample has an albite-oligoclase composition of $\mathrm{An}_{14.02}$, which may represent a retromorphic component.

Epidote grains occur as symplectites together with quartz, rutile and minor plagioclase surrounding the garnets and are compatible with clinozoisite composition. They have high $\mathrm{FeO}$ at $\sim 8 \%$ and $\mathrm{Al}_{2} \mathrm{O}_{3}$ at 24.63-24.77\%. A general replacement of $\mathrm{Al}$ by $\mathrm{Fe}^{3+}$ depicts substitution in the monoclinic members.

All of the analyzed titanites and a unique rutile spot exhibit homogeneous compositions. Rutile is the second most abundant Ti mineral, reaching modal proportions of $4-12 \%$.

\subsection{Bulk-rock chemistry}

Representative metamafic-ultramafic rock samples of the FMUC were analyzed for their major, trace, and rare earth element (REE) concentrations. In addition, 30 analyses of samples from the FMUC and BMUC reported by Beurlen (1988) were reviewed (Inline Supplementary Table 4 and Appendix D).

The control of lithology and fractional crystallization of cumulus minerals is demonstrated by the existence of some systematic trends of major oxides, as shown in Fig. 5a. The negative correlation of $\mathrm{MgO}$ with $\mathrm{Al}_{2} \mathrm{O}_{3}$ and its positive correlation with $\mathrm{CaO}$ underline a control by fractionation of olivine and clinopyroxene, whereas fractionation of Fe-Ti oxides is revealed in the expanded $\mathrm{TiO}_{2}-\mathrm{MgO}$ plot.

The $\mathrm{Al}_{2} \mathrm{O}_{3}$ content increases from less than $2.67 \mathrm{wt} . \%$ in the olivine cumulates and $2-11.6 \mathrm{wt} \%$ in the metaclinopyroxenites to values between $2.5 \mathrm{wt} . \%$ and $21.8 \mathrm{wt} . \%$ in the metahornblendites/garnet amphibolites. Olivine cumulates also 

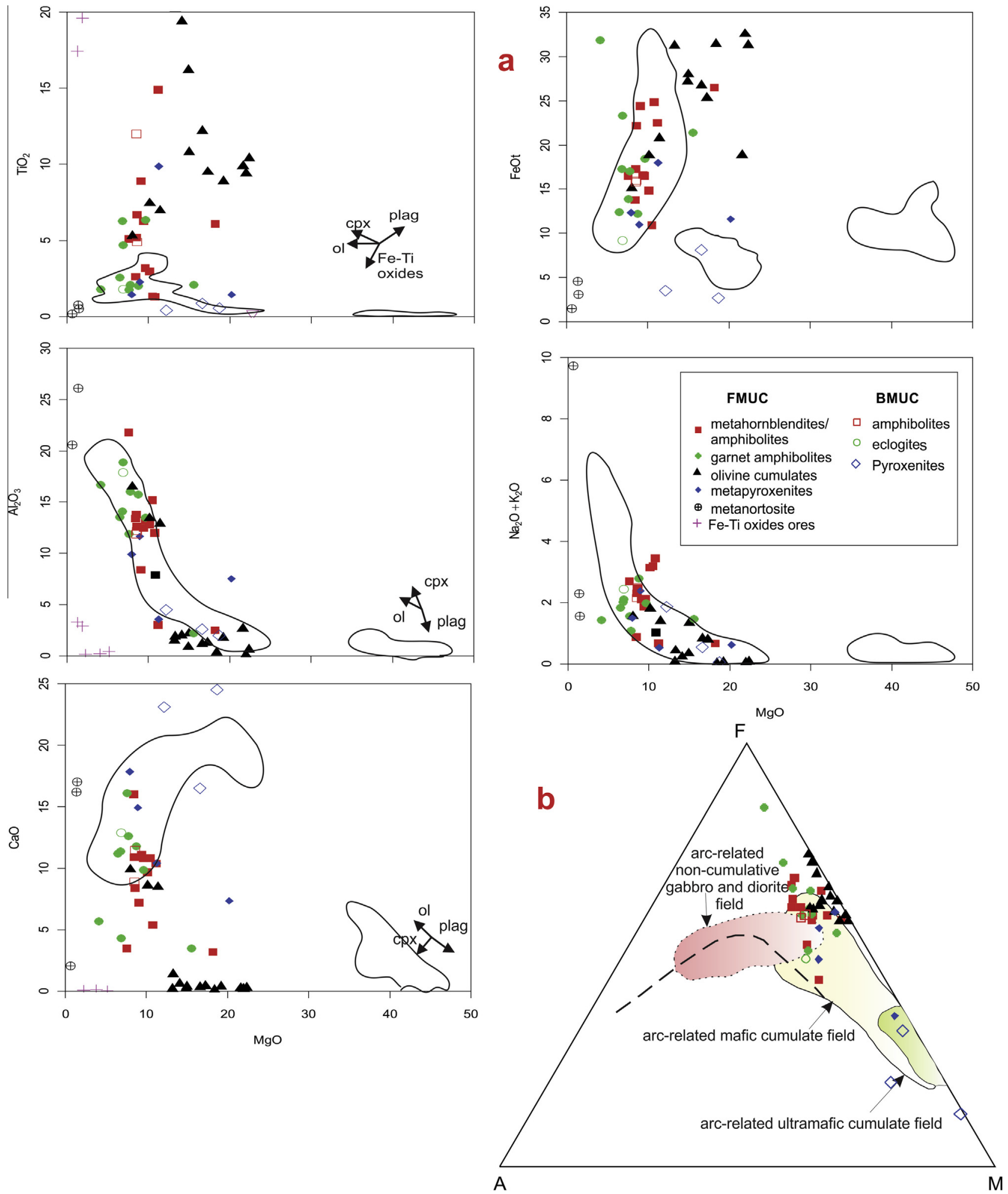

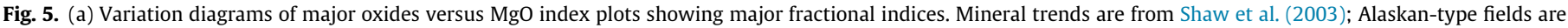

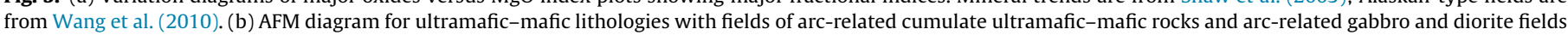
from Beard (1986), after Eyuboglu et al. (2011).

have low $\mathrm{CaO}$ concentrations of less than $1.4 \mathrm{wt} . \%$, whereas the clinopyroxenites have the highest $\mathrm{CaO}$ concentration at 8.9$20.2 \mathrm{wt} . \%$. The $\mathrm{TiO}_{2}$ content is highest in the olivine cumulates at 5.3-25.3 wt.\%, and decreases in the clinopyroxenite and hornblendites/amphibolites at $0.41-2.27 \mathrm{wt} . \%$ and $1.3-14.9 \mathrm{wt} . \%$, respectively.
The peridotites have moderate to high $\mathrm{Ni}$ at $131-2000 \mathrm{ppm}, \mathrm{Cr}$ at $49-2016 \mathrm{ppm}, \mathrm{Co}$ at $82-400 \mathrm{ppm}$ and $\mathrm{Cu}$ at $10.9-1120 \mathrm{ppm}$, and low concentrations of $\mathrm{Rb}$ at $0.5-64 \mathrm{ppm}$ and $\mathrm{Sr}$ at 3.4-58.6 ppm. The pyroxenites have concentrations of $\mathrm{Ni}$ of at $42-1050 \mathrm{ppm}, \mathrm{Cr}$ at 58-2809 ppm, and Co at 11-98.1 ppm as well as a high concentration of $\mathrm{Sr}$ at $15-499 \mathrm{ppm}$. 
For the deposits of Serrote das Pedras Pretas, Riacho da Posse e Riacho da Cachoeira Grande, the $\mathrm{TiO}_{2}$ contents of the samples of massive ore bands of the FMUC show similar values between 40.8 and 44.6 wt.\%. The values of $\mathrm{Fe}_{2} \mathrm{O}_{3}$ vary between 49.84 and 54.05 wt.\%, and the content of $\mathrm{V}$ varies from 2933 to $3633 \mathrm{ppm}$.

In the AFM diagram, the metapyroxenites plot most closely to the $\mathrm{M}$ axis, whereas the olivine cumulates follow a parallel trend to the MF side (Fig. 5b); this result most likely reflects the magnetite-ilmenite mineralization. The majority of amphibolites and gabbroic rocks show a tholeiitic trend overlapping the arcrelated mafic cumulate field. The metapyroxenites are in accordance with an arc-related ultramafic cumulate field.

In the primitive mantle-normalized spider and chondritenormalized REE diagrams, the pyroxenites and amphibolites/meta hornblendites show similar distribution patterns (Fig. 6a-d) characterized by slight enrichment of large ion lithophile elements
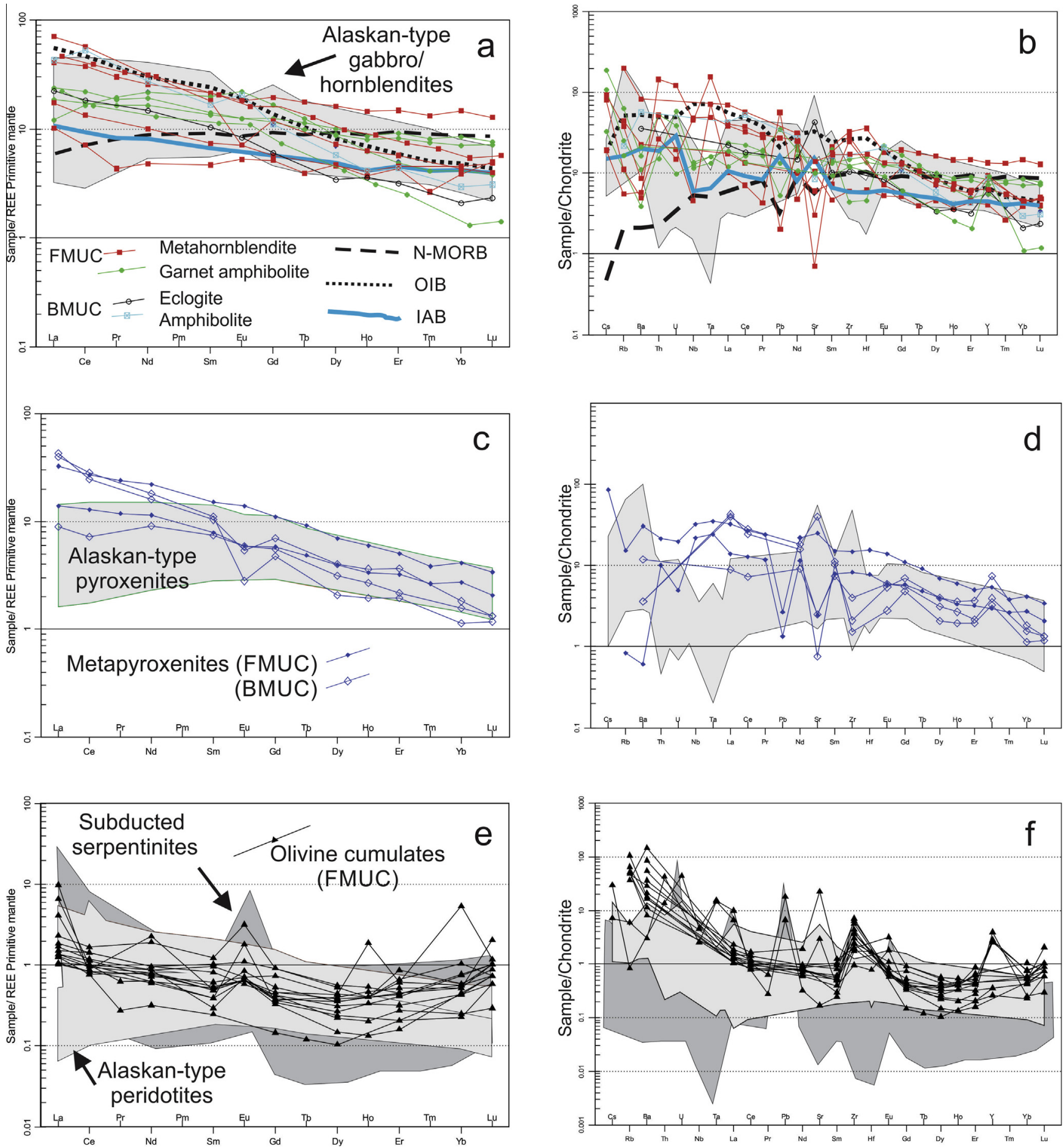

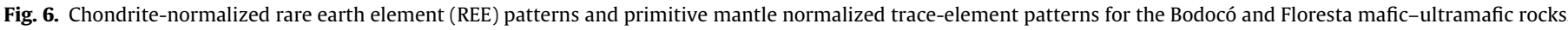

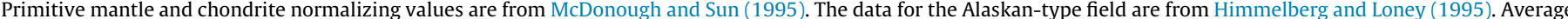

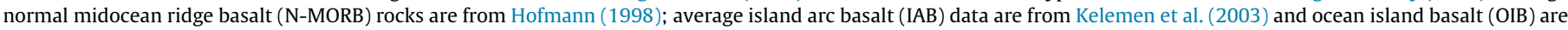
from Sun and McDonough (1989). The data for subducted serpentinites are from Deschamps et al. (2013). 
(LILE) and high field strength elements (HFSE) with respect to the primitive mantle. The chondrite-normalized patterns of the amphi bolites/metahornblendites exhibit slight enrichment in LREE relative to HREE patterns (Fig. 6a and b). Furthermore, garnet amphibolites show more pronounced negative $\mathrm{Nb}, \mathrm{Ta}, \mathrm{Zr}$ and $\mathrm{Hf}$ anomalies when compared with metahornblendites and metapyroxenites. Strong negative $\mathrm{Sr}$ troughs and a positive peak of $\mathrm{Y}$ are also present in mafic members. The plots of garnet amphibolites and metahornblendites overlap with the island arc basalt (IAB) and ocean island basalt (OIB) trends and lie distinctly away from the average normal midocean ridge basalts (N-MORB). In the primitive mantle-normalized diagram, the metapyroxenites exhibit regular trace element patterns (Fig. 6d) and are commonly characterized by troughs for $\mathrm{Pb}, \mathrm{Sr}, \mathrm{Zr}$, and $\mathrm{Y}$.

The patterns for peridotites have smooth MREE and HREE slopes (Fig. 6e) and show a characteristic U-shaped pattern similar to that in harzburgites and wehrlites. The primitive mantle normalized peridotite spider diagram shows a well-marked positive $\mathrm{Pb}$ anomaly and enriched fluid mobile elements including $\mathrm{Cs}, \mathrm{Rb}$, Th, and $U$, suggesting the percolation of fluid during the superimposed subduction process.

\subsection{Isotopic data}

\subsubsection{Zircon LA-MC-ICP-MS U-Pb geochronology}

Zircon grains were separated from a coarse meta-hornblendite sample (GL-02_SPP) collected from the Serrote das Pedras Pretas mine within the FMUC. These zircon grains are prismatic in shape and are formed by two distinct phases: older, homogeneous or growth-zoned cores with locally occurring traces of earlier resorption and recrystallization and coarse metamorphic rims that are generally homogeneous and are separated from cores by irregular interfaces indicative of corrosion (Fig. 7a). These textures are common in zircons from high-grade metamorphic rocks such as eclogites and granulites (Corfu et al., 2003).

The cores of zircon grains have high $\mathrm{Th} / \mathrm{U}$ values at $0.117-0.990$, and they define an upper intercept age of $1024 \pm 18 \mathrm{Ma}$ (MSWD $=4.2$; Table 5; Fig. $7 \mathrm{~b}$ ); this is interpreted as the crystallization age of the FMUC. A core spot (\#COMP2_016-Z9) with a $\mathrm{Th} / \mathrm{U}$ value lower than 0.1 yielded a discordant ${ }^{207} \mathrm{~Pb} /{ }^{206} \mathrm{~Pb}$ value of $1030 \pm 11 \mathrm{Ma}(\sigma 1)$ and ${ }^{238} \mathrm{U} /{ }^{206} \mathrm{~Pb}$ of $967 \pm 9 \mathrm{Ma}$. The age of this grain, even considering the limits of the analysis by LA, may suggest evidence of concomitant metamorphic processes during the
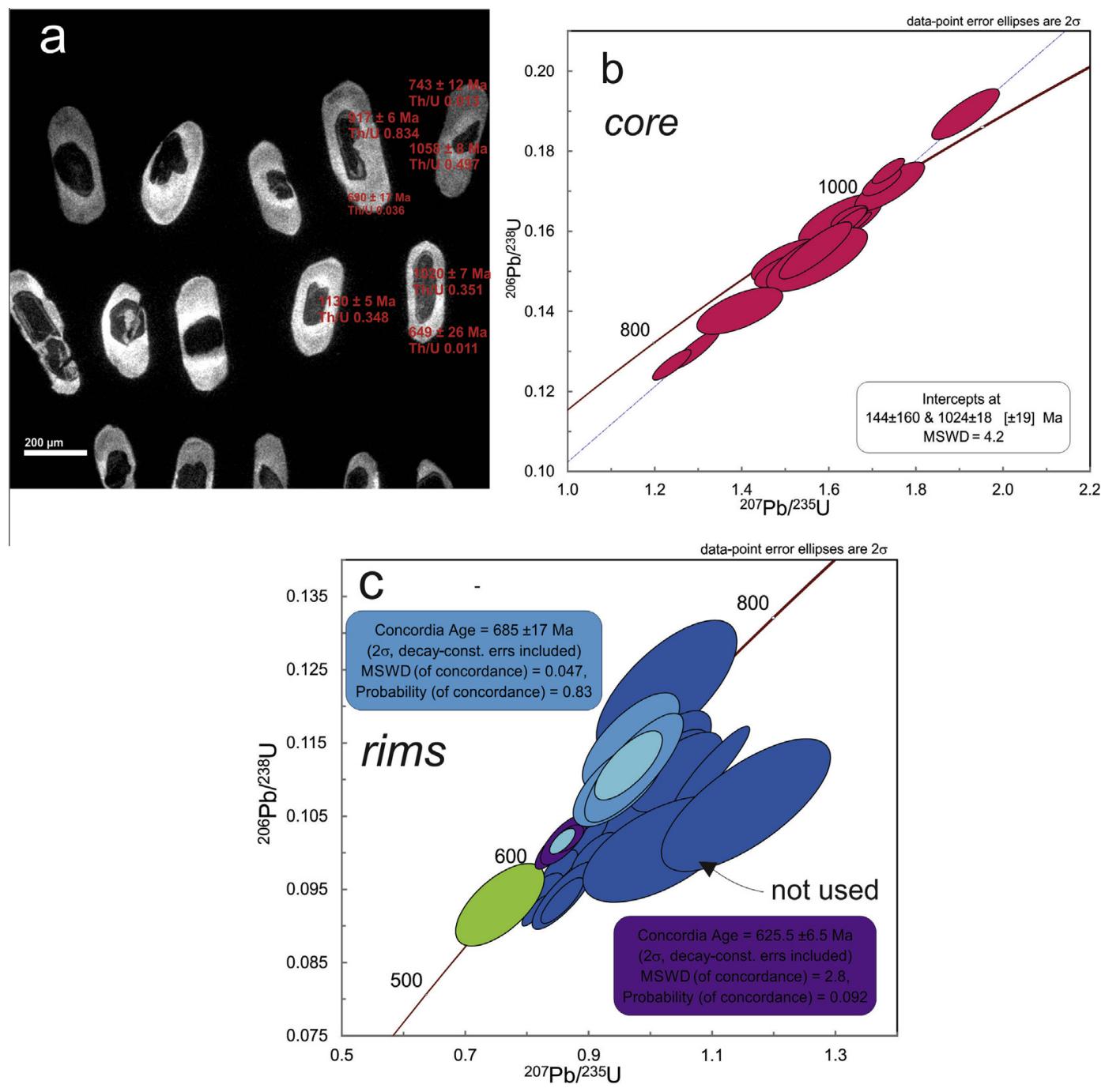

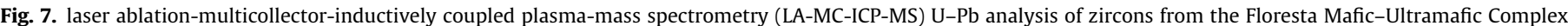

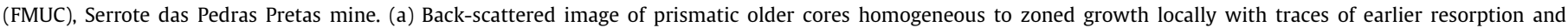

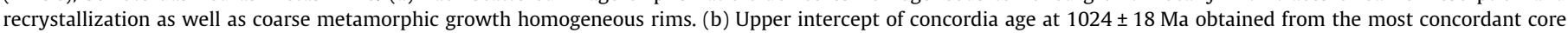
grains. (c) Concordia ages at $685 \pm 18 \mathrm{Ma}$ and $625 \pm 6 \mathrm{Ma}$ obtained from the rims of zircon grains. 
Table 5

LA-ICP-MS U-Th-Pb results for zircons from metahornblendite within Floresta Mafic-Ultramafic Complex (FMUC; Serrote das Pedras Pretas Mine).

\begin{tabular}{|c|c|c|c|c|c|c|c|c|c|c|c|c|c|c|c|c|}
\hline \multirow[t]{2}{*}{ Samples Spots } & \multirow[t]{2}{*}{$\mathrm{Th} / \mathrm{U}$} & \multicolumn{7}{|l|}{ Ratios } & \multirow[t]{2}{*}{$\rho$} & \multicolumn{6}{|c|}{ Apparent Ages } & \multirow[t]{2}{*}{ Conc. (\%) } \\
\hline & & $\frac{206 \mathrm{~Pb}}{204 \mathrm{~Pb}}$ & $\begin{array}{l}207 \mathrm{~Pb} \\
{ }^{206} \mathrm{~Pb}\end{array}$ & $\pm 1 \sigma$ & $\frac{{ }^{207} \mathrm{~Pb}}{235 \mathrm{U}}$ & $\pm 1 \sigma$ & $\frac{206 \mathrm{~Pb}}{238 \mathrm{U}}$ & $\pm 1 \sigma$ & & $\frac{{ }^{207} \mathrm{~Pb}}{206 \mathrm{U}}$ & (Ma) & $\frac{207 \mathrm{~Pb}}{235 \mathrm{U}}$ & (Ma) & $\frac{206 \mathrm{~Pb}}{238 \mathrm{U}}$ & (Ma) & \\
\hline \multicolumn{17}{|l|}{ GL-02_SPP } \\
\hline \multicolumn{17}{|l|}{ Cores } \\
\hline $008-Z 3 N$ & 0.351 & 51,013 & 0.07323 & 0.36 & 1.5439 & 0.93 & 0.152919 & 0.86 & 0.91 & 1020 & 7 & 948 & 6 & 917 & 7.36 & 97 \\
\hline 009-Z3M & 0.342 & 2358 & 0.07100 & 0.80 & 1.2402 & 1.46 & 0.126686 & 1.22 & 0.85 & 957 & 16 & 819 & 8 & 769 & 8.85 & 94 \\
\hline $040-Z 21 N$ & 0.541 & 237,702 & 0.07470 & 0.26 & 1.6684 & 0.76 & 0.161979 & 0.72 & 0.93 & 1061 & 5 & 997 & 5 & 968 & 6.46 & 97 \\
\hline 011-Zir3N & 0.630 & 69,429 & 0.07367 & 0.0007 & 1.5914 & 1.35 & 0.156670 & 0.89 & 0.66 & 1032 & 19 & 967 & 8 & 938 & 7.78 & 91 \\
\hline 012-Zir4 & 0.688 & 70,845 & 0.07269 & 0.0006 & 1.6435 & 1.25 & 0.163966 & 0.86 & 0.69 & 1005 & 17 & 987 & 8 & 979 & 7.82 & 97 \\
\hline 017-Zir7 & 0.315 & 26,989 & 0.07252 & 0.0012 & 1.6279 & 2.41 & 0.162787 & 1.65 & 0.69 & 1001 & 34 & 981 & 15 & 972 & 14.90 & 97 \\
\hline 021-Zir9N & 0.618 & 39,088 & 0.07195 & 0.0005 & 1.2954 & 1.72 & 0.130571 & 1.53 & 0.89 & 984 & 14 & 844 & 10 & 791 & 11.41 & 20 \\
\hline 028-Zir11 & 0.605 & 56,401 & 0.07375 & 0.0008 & 1.7411 & 1.88 & 0.171202 & 1.47 & 0.78 & 1035 & 22 & 1024 & 12 & 1019 & 13.86 & 98 \\
\hline 034-Zir15N & 0.990 & 94,212 & 0.07337 & 0.0006 & 1.9157 & 1.66 & 0.189345 & 1.36 & 0.82 & 1024 & 17 & 1087 & 11 & 1118 & 13.99 & 109 \\
\hline 040-Zir18 & 0.802 & 11,823 & 0.07460 & 0.0012 & 1.5861 & 1.79 & 0.154196 & 0.57 & 0.32 & 1058 & 33 & 965 & 11 & 924 & 4.87 & 87 \\
\hline 047-Zir21 & 0.625 & 20,151 & 0.07149 & 0.0012 & 1.5054 & 2.24 & 0.152699 & 1.4379 & 0.64 & 972 & 34 & 933 & 14 & 916 & 12.27 & 94 \\
\hline COMP_006-Z6N & 0.418 & 86,207 & 0.07214 & 1.32 & 1.4943 & 1.75 & 0.150236 & 1.14 & 0.64 & 931 & 28 & 928 & 11 & 902 & 9.64 & 97 \\
\hline COMP_012-Z31N & 0.452 & 37,481 & 0.07301 & 0.91 & 1.5507 & 1.41 & 0.154041 & 1.08 & 0.75 & 956 & 19 & 951 & 9 & 924 & 9.29 & 97 \\
\hline COMP_018-Z33N & 0.225 & 61,409 & 0.07308 & 0.56 & 1.5399 & 0.93 & 0.152825 & 0.75 & 0.77 & 958 & 12 & 946 & 6 & 917 & 6.41 & 97 \\
\hline COMP2_011-Z6 & 0.555 & 104,549 & & & 1.7232 & 1.05 & 0.172355 & 0.81 & 0.74 & 1000 & 14 & 1017 & 7 & 1025 & 7.64 & 102 \\
\hline COMP2_012-Z7 & 0.556 & 54,211 & & & 1.6484 & 1.04 & 0.163601 & 0.72 & 0.66 & 1016 & 15 & 989 & 7 & 977 & 6.57 & 96 \\
\hline COMP2_024-Z15 & 0.155 & 12,482 & & & 1.5738 & 3.01 & 0.153021 & 2.13 & 0.70 & 1058 & 43 & 960 & 19 & 918 & 18.22 & 87 \\
\hline COMP2_035-Z21 & 0.580 & 233,296 & & & 1.7382 & 0.87 & 0.175112 & 0.74 & 0.82 & 986 & 10 & 1023 & 6 & 1040 & 7.09 & 106 \\
\hline COMP2_048-Z29 & 0.117 & 111,249 & & & 1.5707 & 2.17 & 0.155274 & 1.88 & 0.86 & 1024 & 22 & 959 & 13 & 930 & 16.25 & 91 \\
\hline COMP2_052-Z31 & 0.133 & 1194 & & & 1.3966 & 2.89 & 0.140187 & 1.70 & 0.64 & 993 & 47 & 888 & 17 & 846 & 13.49 & 85 \\
\hline COMP2_016-Z9 & 0.037 & 8703 & & & 1.6425 & 1.15 & 0.161898 & 1.02 & 0.87 & 1030 & 11 & 987 & 7 & 967 & 9.14 & 94 \\
\hline \multicolumn{17}{|l|}{ Rims } \\
\hline 007-Z2B & 0.013 & 21,174 & 0.06404 & 0.56 & 0.8131 & 1.07 & 0.092081 & 0.92 & 0.84 & 743 & 12 & 604 & 5 & 568 & 4.98 & 94 \\
\hline 019-Z10B & 0.038 & 6103 & 0.06611 & 1.34 & 0.8583 & 2.40 & 0.094158 & 1.99 & 0.83 & 810 & 28 & 629 & 11 & 580 & 11.05 & 92 \\
\hline 020-Z11B & 0.018 & 4616 & 0.06310 & 0.92 & 0.8533 & 1.35 & 0.098084 & 0.98 & 0.72 & 711 & 20 & 626 & 6 & 603 & 5.62 & 96 \\
\hline 023-Z12B & 0.015 & 20,870 & 0.06364 & 0.93 & 0.8986 & 1.46 & 0.102409 & 1.12 & 0.76 & 730 & 20 & 651 & 7 & 629 & 6.71 & 97 \\
\hline 025-Z13B & 0.011 & 7820 & 0.06128 & 1.19 & 0.8601 & 1.82 & 0.101796 & 1.37 & 0.75 & 649 & 26 & 630 & 9 & 625 & 8.16 & 99 \\
\hline 027-Z14B & 0.008 & 20,281 & 0.06164 & 0.92 & 0.8666 & 1.18 & 0.101958 & 0.75 & 0.59 & 662 & 20 & 634 & 6 & 626 & 4.46 & 99 \\
\hline 029-Z15B & 0.010 & 5178 & 0.06077 & 0.87 & 0.8433 & 1.45 & 0.100645 & 1.16 & 0.79 & 631 & 19 & 621 & 7 & 618 & 6.86 & 100 \\
\hline 036-Z18B & 0.008 & 5477 & 0.06331 & 1.16 & 0.8254 & 1.64 & 0.094556 & 1.16 & 0.70 & 719 & 25 & 611 & 8 & 582 & 6.48 & 95 \\
\hline 048-Z26B & 0.024 & 7713 & 0.06645 & 0.92 & 0.8566 & 1.64 & 0.093498 & 1.37 & 0.82 & 821 & 19 & 628 & 8 & 576 & 7.53 & 92 \\
\hline 049-Z27B & 0.008 & 7843 & 0.06598 & 1.08 & 0.9081 & 1.63 & 0.099816 & 1.22 & 0.74 & 806 & 23 & 656 & 8 & 613 & 7.16 & 93 \\
\hline COMP2_051-Z30 & 0.008 & 19,020 & & & 0.9498 & 3.22 & 0.109569 & 2.23 & 0.69 & 704 & 50 & 678 & 16 & 670 & 14.18 & 95 \\
\hline COMP2_015-Z8 & 0.011 & 21,443 & & & 0.9686 & 3.32 & 0.115257 & 2.35 & 0.70 & 637 & 51 & 688 & 17 & 703 & 15.64 & 110 \\
\hline COMP2_046-Z27 & 0.010 & 26,738 & & & 0.9736 & 3.37 & 0.111634 & 2.73 & 0.81 & 717 & 42 & 690 & 17 & 682 & 17.67 & 95 \\
\hline 035-Zir15B & 0.010 & 21,220 & 0.05900 & 2.96 & 0.7559 & 3.88 & 0.092922 & 2.48 & 0.64 & 567 & 63 & 572 & 17 & 573 & 13.59 & 101 \\
\hline \multicolumn{17}{|l|}{ Inheritance } \\
\hline COMP_011-Z30N & 0.256 & 162,785 & 0.12426 & 1.90 & 5.6729 & 3.15 & 0.331103 & 2.51 & 0.80 & 1968 & 35 & 1927 & 27 & 1844 & 40.33 & 96 \\
\hline COMP_021-Z27N & 0.431 & 130,943 & 0.11016 & 0.82 & 3.3566 & 1.03 & 0.220994 & 0.62 & 0.54 & 1750 & 15 & 1494 & 8 & 1287 & 7.18 & 86 \\
\hline COMP_022-Z34N & 0.436 & 129,607 & 0.11146 & 0.88 & 3.3241 & 1.59 & 0.216292 & 1.33 & 0.83 & 1771 & 16 & 1487 & 12 & 1262 & 15.24 & 85 \\
\hline
\end{tabular}

Tonian Period. Data points of zircon rims with metamorphic margins have systematically low $\mathrm{Th} / \mathrm{U}$ values that range between 0.008 and 0.038 . Two concordia ages of $685 \pm 17 \mathrm{Ma}(\mathrm{MSWD}=0.047)$ and $625 \pm 6 \mathrm{Ma}$ (MSWD = 2.8; Table 5; Fig. 7c) are identified as the progressive ages of high-grade metamorphism. Three xenocrystic zircons denote inheritance at ca. $1.9 \mathrm{Ga}$ that cannot be correlated with any known event in the exposed basement rocks.

\subsubsection{Sr-Nd Isotopes}

One sample of each facies from Serrote das Pedras Pretas (GL02), Riacho da Posse (GL-08) and Lagoa dos Angicos (AM-445) within the Riacho do Icó granite and the Tapuio (GL-04) and the Caraibeiras (AM-448 and AM-456), folded along with the São Caetano schist, were analyzed for $\mathrm{Sr}-\mathrm{Nd}$ isotopes (Table 6).

The Sm-Nd whole-rock isochronal age obtained for 12 samples from the FMUC yields an age of $1028 \pm 63 \mathrm{Ma}(\mathrm{MSWD}=0.79)$ with an initial $\varepsilon N d(t)$ of 2.1 (Fig. 8a), which is also interpreted as a possible protolith age of the FMUC. The obtained Sm-Nd isochron age is quite similar to that obtained by the $\mathrm{U}-\mathrm{Pb}$ method considering the uncertainty.

The initial isotopic ratios were calculated on the basis of $1024 \mathrm{Ma}$ (Fig. 7b). The $\left({ }^{143} \mathrm{Nd} /{ }^{144} \mathrm{Nd}\right)_{i}$ of the FMUC mafic-ultramafic rocks range from 0.511317 to 0.511564 , and the $\varepsilon \mathrm{Nd}(t)$ values are in the range of $0.01-4.84$. With the exception of two samples, their $\mathrm{T}_{\mathrm{DM}}$ values range between 1.1 and $1.6 \mathrm{Ga}$ suggesting that their protoliths were derived from a juvenile Mesoproterozoic asthenospheric source or a mixed Paleo and Neoproterozoic source.

The initial ratios, expressed as positive $\varepsilon N d(t)$ of 2.1 and obtained in the isochron (Fig. 8a) and Nd isotopic growth diagram (Fig. 8b), reveal that the original magma was not contaminated by the older crust. The $\varepsilon N d(t)$ values indicate a depleted mantle source with values close to the chondritic uniform reservoir (CHUR). The Sr-isotopic ratios vary markedly among the FMUC lithologies. The metahornblendite samples have $\left({ }^{87} \mathrm{Sr} /{ }^{86} \mathrm{Sr}\right) i$ values of 0.7039 to 0.7076 ; garnet amphibolites vary consistently within $\left({ }^{87} \mathrm{Sr} /{ }^{86} \mathrm{Sr}\right) i$ values of 0.7010 to 0.7090 ; and metapyroxenite samples show lower $\left({ }^{87} \mathrm{Sr} /{ }^{86} \mathrm{Sr}\right) i$ values of $0.7029-0.7034$. The combined data suggest an isotopically enriched mantle reservoir similar to enriched mantle type II (EM-II), particularly in ${ }^{87} \mathrm{Sr} /{ }^{86} \mathrm{Sr}$.

\section{Discussion}

\subsection{Petrogenesis and tectonic settings}

Proper petrologic features that are present in Alaskan-type complexes and considered to be consistent with an arc environment 
Table 6

$\mathrm{Sm}-\mathrm{Nd}$ and $\mathrm{Sr}-\mathrm{Sr}$ data obtained for Floresta Mafic-Ultramafic Complex (FMUC).

\begin{tabular}{|c|c|c|c|c|c|c|c|c|c|c|c|c|c|c|c|c|c|c|}
\hline Sample & Rock/mineral & Location & UTM N & UTM E & $\mathrm{Sm}$ & $\mathrm{Nd}$ & ${ }^{147} \mathrm{Sm} /{ }^{144} \mathrm{Nd}$ & ${ }^{143} \mathrm{Nd} /{ }^{144} \mathrm{Nd}$ & $\pm 2 \sigma$ & $\begin{array}{l}\varepsilon N d \\
(0)\end{array}$ & $\begin{array}{l}\varepsilon \mathrm{Nd}(t) \\
t=1024 \mathrm{Ma}\end{array}$ & $T_{D M}$ & $\mathrm{Rb}$ & $\mathrm{Sr}$ & ${ }^{87} \mathrm{Sr} /{ }^{86} \mathrm{Sr}$ & $\pm 2 \sigma$ & ${ }^{143} \mathrm{Nd} /{ }^{144} \mathrm{Nd}_{\mathrm{i}}$ & ${ }^{87} \mathrm{Sr} /{ }^{86} \mathrm{Sr}_{\mathrm{i}}$ \\
\hline GLO2(M)A & Metahornblendite & $\begin{array}{l}\text { Serrote das } \\
\text { Pedras Pretas }\end{array}$ & 547,817 & $9,062,566$ & 9 & 34.671 & 0.1569 & 0.512516 & 0.000001 & -2.38 & 2.84 & 1.40 & & & & & 0.511462 & \\
\hline GL 02(M)B & $\begin{array}{l}\text { Garnet } \\
\text { amphibolite }\end{array}$ & $\begin{array}{l}\text { Serrote das } \\
\text { Pedras Pretas }\end{array}$ & & & 7.756 & 24.548 & 0.191 & 0.512636 & 0.000012 & -0.05 & 0.71 & & & & & & 0.511353 & 0.7058 \\
\hline GL 02(M)C & Fe-Ti-V cumulus & $\begin{array}{l}\text { Serrote das } \\
\text { Pedras Pretas }\end{array}$ & & & 0.032 & 0.111 & 0.1718 & 0.512487 & 0.000012 & -2.94 & 0.32 & 2.00 & & & & & 0.511333 & \\
\hline GL-02A & Metahornblendite & $\begin{array}{l}\text { Serrote das } \\
\text { Pedras Pretas }\end{array}$ & & & 8.902 & 31.361 & 0.1716 & 0.512537 & 0.000009 & -1.97 & 1.32 & 1.80 & 14.7 & 124.7 & 0.7126 & 0.00001 & 0.511384 & 0.7076 \\
\hline GL2B & $\begin{array}{l}\text { Garnet } \\
\text { amphibolite }\end{array}$ & $\begin{array}{l}\text { Serrote das } \\
\text { Pedras Pretas }\end{array}$ & & & 3.92 & 11.96 & 0.1981 & 0.512648 & 0.000007 & 0.2 & 0.01 & & 15.3 & 196.3 & 0.7091 & 0.00001 & 0.511317 & 0.7058 \\
\hline GL2E & Olivine cumulate & $\begin{array}{l}\text { Serrote das } \\
\text { Pedras Pretas }\end{array}$ & & & 0.639 & 1.574 & 0.2452 & 0.513064 & 0.000004 & 8.31 & 2.18 & & & & & & 0.511416 & \\
\hline AM-446C & Metahornblendite & $\begin{array}{l}\text { Serrote das } \\
\text { Pedras Pretas }\end{array}$ & & & 7.961 & 33.961 & 0.1417 & 0.512433 & 0.000021 & -4.00 & 3.22 & 1.28 & & & & & 0.511481 & \\
\hline AM-446D & $\begin{array}{l}\text { Garnet } \\
\text { amphibolite }\end{array}$ & $\begin{array}{l}\text { Serrote das } \\
\text { Pedras Pretas }\end{array}$ & & & 1.009 & 1.9601 & 0.3111 & 0.513411 & 0.00002 & 15.08 & 0.08 & & & & & & 0.511321 & \\
\hline GL 04(M)A & $\begin{array}{l}\text { Coarse } \\
\text { hornblendite }\end{array}$ & $\begin{array}{l}\text { Riacho Tapuio/ } \\
\text { Arapuá }\end{array}$ & 551,344 & $9,067,350$ & 7.095 & 31.599 & 0.1357 & 0.512328 & 0.000007 & -6.04 & 1.95 & 1.38 & & & & & 0.511416 & \\
\hline GL 04(M)C & Tremolitite & $\begin{array}{l}\text { Riacho Tapuio/ } \\
\text { Arapuá }\end{array}$ & & & 3.037 & 12.414 & 0.1479 & 0.512386 & 0.000005 & -4.92 & 1.48 & 1.50 & & & & & 0.511392 & \\
\hline GL 04(M)D & Pyroxenite & $\begin{array}{l}\text { Riacho Tapuio/ } \\
\text { Arapuá }\end{array}$ & & & 6.408 & 28.083 & 0.1379 & 0.512353 & 0.000008 & -5.56 & 2.15 & 1.38 & & & & & 0.511426 & \\
\hline GL-04A & Metahornblendite & $\begin{array}{l}\text { Riacho Tapuio/ } \\
\text { Arapuá }\end{array}$ & & & 6.357 & 29.423 & 0.1306 & 0.512317 & 0.000008 & -6.25 & 2.41 & 1.32 & 3.3 & 274.4 & 0.7044 & 0.00001 & 0.511439 & 0.7039 \\
\hline GL-04B & $\begin{array}{l}\text { Garnet } \\
\text { amphibolite }\end{array}$ & $\begin{array}{l}\text { Riacho Tapuio/ } \\
\text { Arapuá }\end{array}$ & & & 5.618 & 20.576 & 0.1651 & 0.512673 & 0.000012 & 0.69 & 4.84 & 1.15 & 6.7 & 305 & 0.7099 & 0.00001 & 0.511564 & 0.7090 \\
\hline GL-04C & Pyroxenite & $\begin{array}{l}\text { Riacho Tapuio/ } \\
\text { Arapuá }\end{array}$ & & & 3.149 & 11.748 & 0.162 & 0.512495 & 0.000017 & -2.79 & 1.76 & 1.60 & 0.5 & 49 & 0.7038 & 0.00001 & 0.511406 & 0.7034 \\
\hline GL-04D & Pyroxenite schist & $\begin{array}{l}\text { Riacho Tapuio/ } \\
\text { Arapuá }\end{array}$ & & & 6.454 & 28.41 & 0.1373 & 0.512347 & 0.000011 & -5.68 & 2.11 & 1.38 & 9.2 & 499.8 & 0.7036 & 0.00001 & 0.511424 & 0.7029 \\
\hline GL 08(M)A & Metahornblendite & Riacho da Posse & 544,582 & $9,061,535$ & 9.814 & 38.368 & 0.1546 & 0.512452 & 0.000013 & -3.63 & 1.89 & 1.51 & & & & & 0.511413 & \\
\hline GL 08(M)C & Fe-Ti-V cumulus & Riacho da Posse & & & 0.034 & 0.126 & 0.1625 & 0.512501 & 0.000014 & -2.67 & 1.82 & 1.59 & & & & & 0.511409 & \\
\hline GL-08A & Metahornblendite & Riacho da Posse & & & 15.077 & 67.538 & 0.1349 & 0.512298 & 0.000006 & -6.64 & 1.47 & 1.43 & 6.7 & 60 & 0.7117 & 0.00001 & 0.511392 & 0.7070 \\
\hline GL-08B & $\begin{array}{l}\text { Garnet } \\
\text { amphibolite }\end{array}$ & Riacho da Posse & & & 5.483 & 19.486 & 0.1701 & 0.512656 & 0.000008 & 0.36 & 3.85 & 1.33 & 38.4 & 202.4 & 0.7090 & 0.00001 & 0.511513 & 0.7010 \\
\hline AM-445E & Olivine cumulate & $\begin{array}{l}\text { Lagoa dos } \\
\text { Angicos }\end{array}$ & 546,436 & $9,061,525$ & 1.447 & 3.835 & 0.2281 & 0.512976 & 0.000013 & 6.59 & 2.48 & & & & & & 0.511443 & \\
\hline AM-448A & $\begin{array}{l}\text { Garnet } \\
\text { amphibolite }\end{array}$ & Caraibeiras road & & & 5.538 & 23.432 & 0.1429 & 0.512439 & 0.000038 & -3.89 & 3.18 & 1.29 & & & & & 0.511479 & \\
\hline AM-448D & Metahornblendite & Caraibeiras road & 549,944 & $9,066,921$ & 3.232 & 14.324 & 0.1364 & 0.512401 & 0.000013 & -4.63 & 3.29 & 1.26 & & & & & 0.511484 & \\
\hline AM-456A & $\begin{array}{l}\text { Garnet } \\
\text { amphibolite }\end{array}$ & Caraibeiras & 549,195 & $9,067,122$ & 3.871 & 16.132 & 0.1451 & 0.512424 & 0.000006 & -4.17 & 2.6 & 1.36 & & & & & 0.511449 & \\
\hline
\end{tabular}



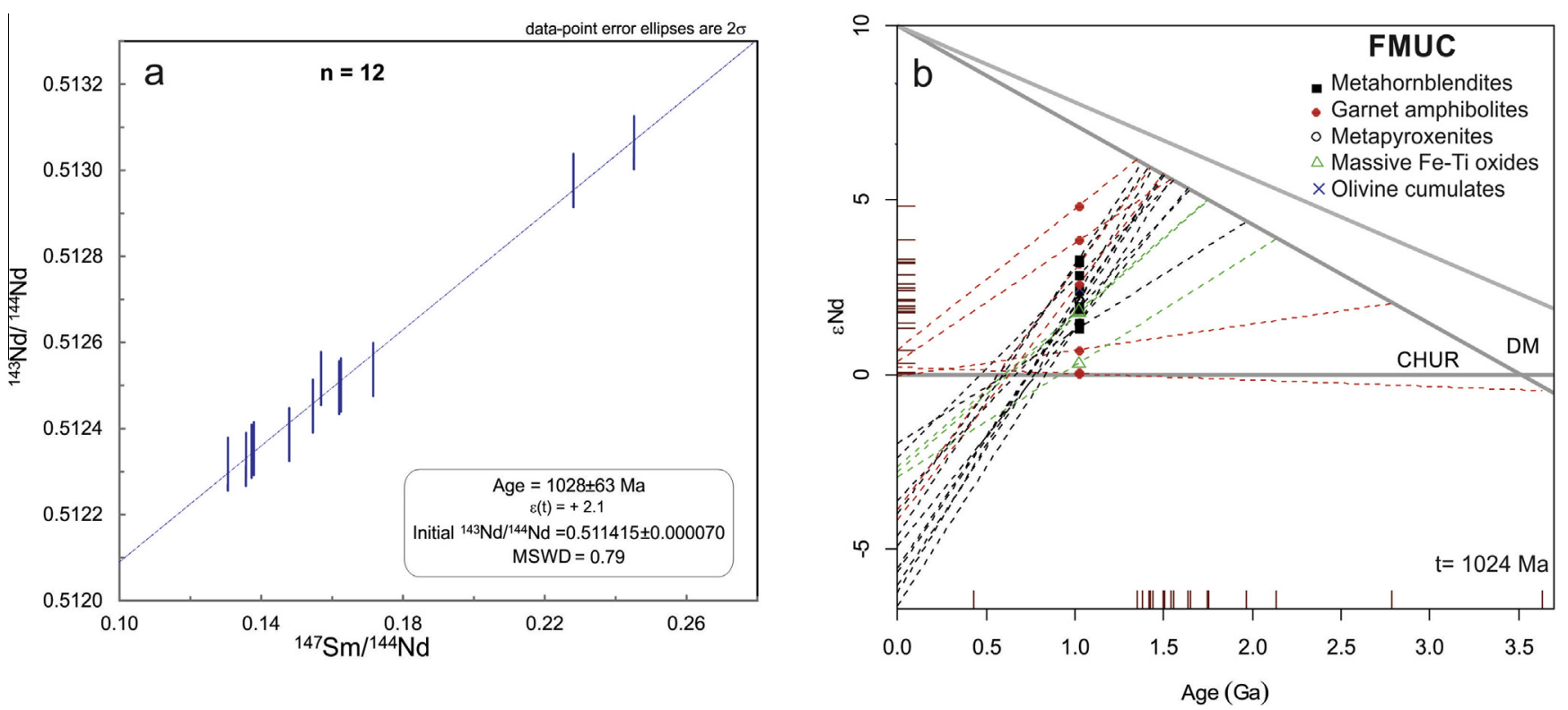

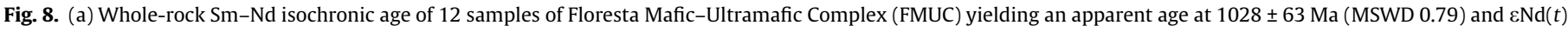
parameter of 2.1; (b) Nd evolution diagram of the FMUC from calculated age of $1024 \mathrm{Ma}$.

include cumulative clinopyroxene, the presence of hornblende, and commonly the absence of orthopyroxene and plagioclase (Eyuboglu et al., 2010; Helmy and El Mahallawi, 2003; Johan, 2002; Pettigrew and Hattori, 2006; Ripley, 2009; Su et al., 2014). Magnetite and ilmenite are common opaque minerals with modal abundances of $\sim 15-$ 20\% (Taylor, 1967; Irvine, 1974; Himmelberg and Loney, 1995). Additionally, Mg-rich olivine, Ca-rich clinopyroxene, high Fechromite, and calcic hornblendes with a broad compositional spectrum (Irvine, 1974; Rublee, 1994; Helmy and El Mahallawi, 2003; Su et al., 2012; Farahat and Helmy, 2006) characterize the minerals of Alaskan-type complexes.

The petrologic data underline that the studied ultramafic and mafic rocks are remarkably similar to subduction-related arc cumulates and are analogous to the Island Arc and Alaskan-type complexes. Among the features noted, we highlight the petrography and mineralogy of clinopyroxene, spinel, and amphiboles and the whole-rock chemistry as follows.

\subsubsection{Petrography and mineralogy}

The preferred Ti mineralization with the ultramafic rocks in the FMUC resembles that in the BMUC (Beurlen et al., 1992). Despite the observed intense recrystallization, the Riacho da Posse open pit and particularly the Serrote das Pedras Pretas outcrops indicate the following possible protoliths: a cumulative rock assemblage with a mineralized metadunite core grading into a transitional phase formed by recrystallization of these dunites into tremolitites and then to chlorite-tremolite schists and clinopyroxene-tremo lite-chlorite schists with variable amounts of olivine. The latter is derived from wehrlite and pyroxenite facies. Hbl-gabbros are likely a previous plagioclase-rich phase that formed garnet amphibolites and a rim of coarse to pegmatitic hornblendites. We believe that coarse hornblendites can comprise a separate lithology given that the previous mineral assemblages exhibit the following characteristics: the absence of free plagioclase, the presence of non-oriented euhedral amphiboles, the absence of interstitial fine-grained amphiboles, and the presence of sharp contacts between garnet amphibolites and coarse to pegmatitic metahornblendites that possibly reflects the presence of compositional cumulative layering. Orthopyroxene does not exist or has not been found, and abundant plagioclase, if present, would have been restricted to the gabbroic member that gave rise to the relicts of eclogites. The crystallization order from the existent rocks may be assumed as apatite, olivine, Fe-chromite, clinopyroxene, magnetite, ilmenite, \pm hornblende, \pm plagioclase, sulfides. These rock assemblages are highly similar to typical Alaskan-type cumulate sequences (Himmelberg and Loney, 1995).

\subsubsection{Clinopyroxene chemistry}

Ca enrichment, high $\mathrm{Mg \#}$ and variable $\mathrm{Al}_{2} \mathrm{O}_{3}$ and $\mathrm{TiO}_{2}$ contents of the clinopyroxenes, as well as evidence of crystal accumulation, such as scarce graded layers, show close similarity with the clinopyroxenes from arc-related cumulates/Alaskan-type maficultramafic rocks and are distinguishing features of alpine-type ophiolites and layered intrusions (Himmelberg and Loney, 1995; Farahat and Helmy, 2006; Pettigrew and Hattori, 2006; Krause et al., 2007; Wang et al., 2010; Eyuboglu et al., 2010, 2011). The data plotted in the field of the clinopyroxenes from Alaskan-type complexes and arc-related cumulates (Fig. 9a) in which the high Wo and up to $0.54 \mathrm{wt}$.\% of $\mathrm{Cr}_{2} \mathrm{O}_{3}$ contents of clinopyroxenes reveal that these products are similar to those originating from nearliquidus crystallization of water-bearing basaltic magma (e.g., Sisson and Grove, 1993; Pettigrew and Hattori, 2006; Eyuboglu et al., 2011). Loucks (1990) demonstrated that the trend of the $\mathrm{Al}^{\mathrm{iv}} / \mathrm{TiO}_{2}$ in clinopyroxene in arc cumulates is distinct from that of rift-related tholeiites. This discrimination diagram is presented in Fig. 9b, with the data from the BMUC following an arc cumulate trend and affinity with Alaskan-type complexes. A single grain (rim) plotted outside of the compositional field, where the IAB and MORB trends are similar at low $\mathrm{Al}^{\mathrm{IV}}$ and $\mathrm{TiO}_{2}$ concentrations. However, the Ural-Alaskan-type can be distinguished from MORB magma by their enriched trace element concentrations in the parent magma (Krause et al., 2007). Similar characteristics can be observed in Fig. 9c in the $\mathrm{Al}_{2} \mathrm{O}_{3}-\mathrm{SiO}_{2}-\mathrm{Mg} /\left(\mathrm{Mg}+\mathrm{Fe}^{2+}\right)$ diagram. The trend of alumina enrichment with differentiation and negative correlation with $\mathrm{Mg} \#$ also reflects crystallization of clinopyroxene from progressively more hydrous melts characteristic of arc magmas and high-alumina basaltic magma at convergent plate settings (Murray, 1972; Conrad and Kay, 1984; Loucks, 1990; Himmelberg and Loney, 1995; Wang et al., 2010). 

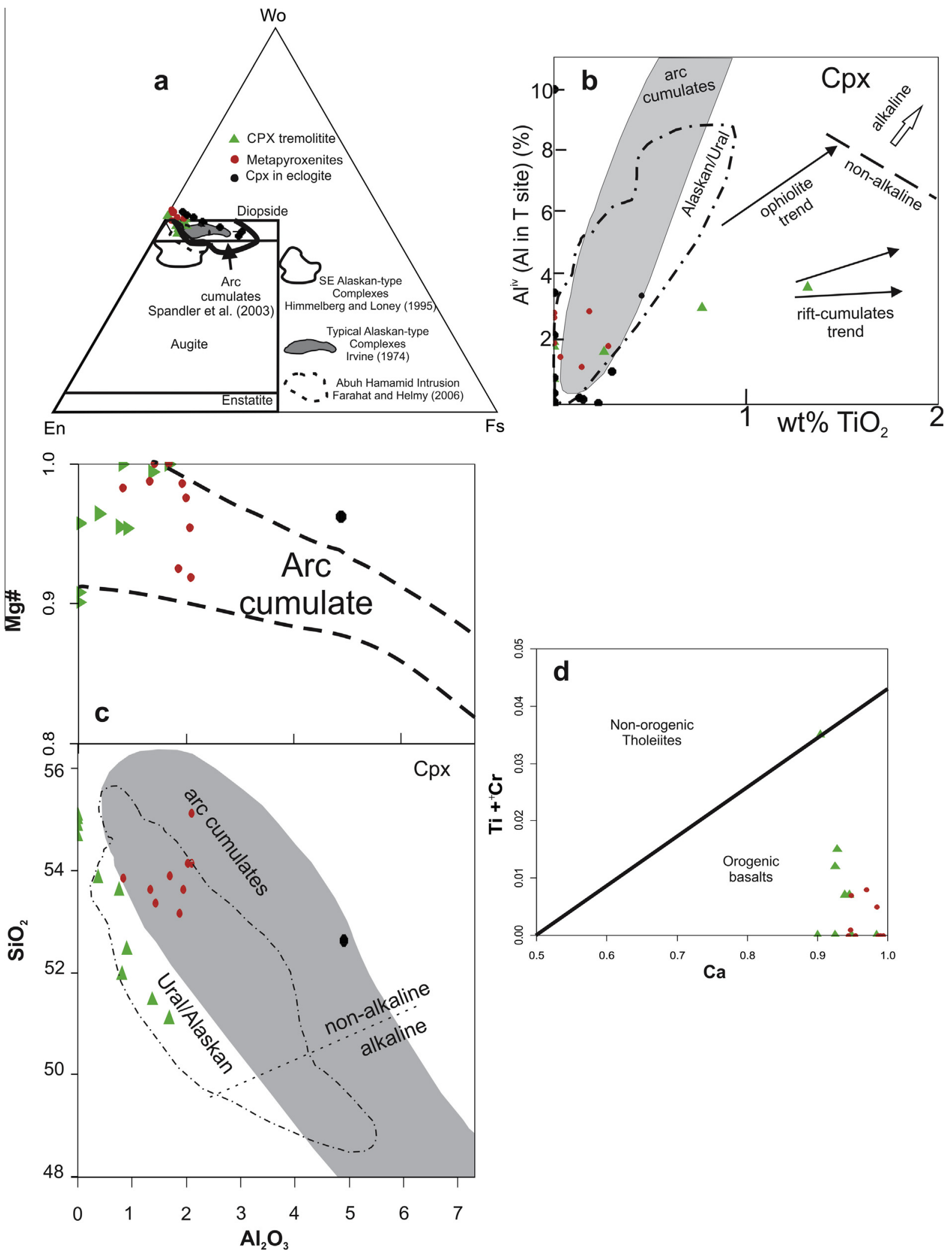

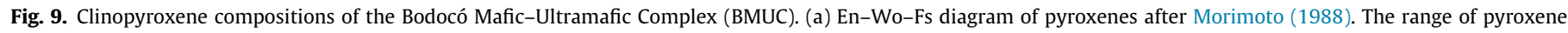

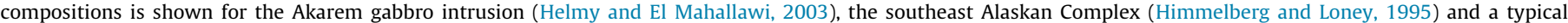

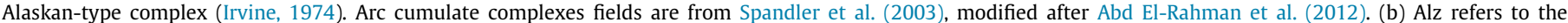

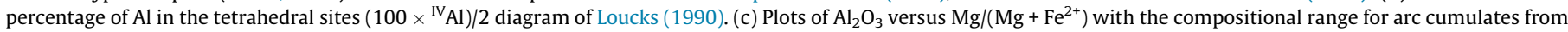

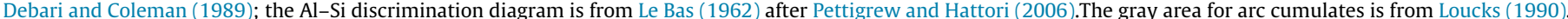

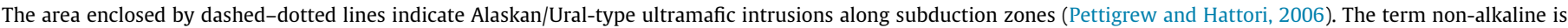

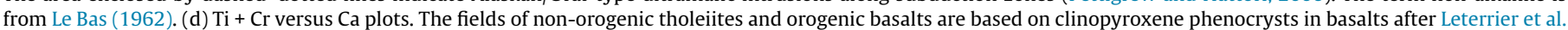
(1982). 

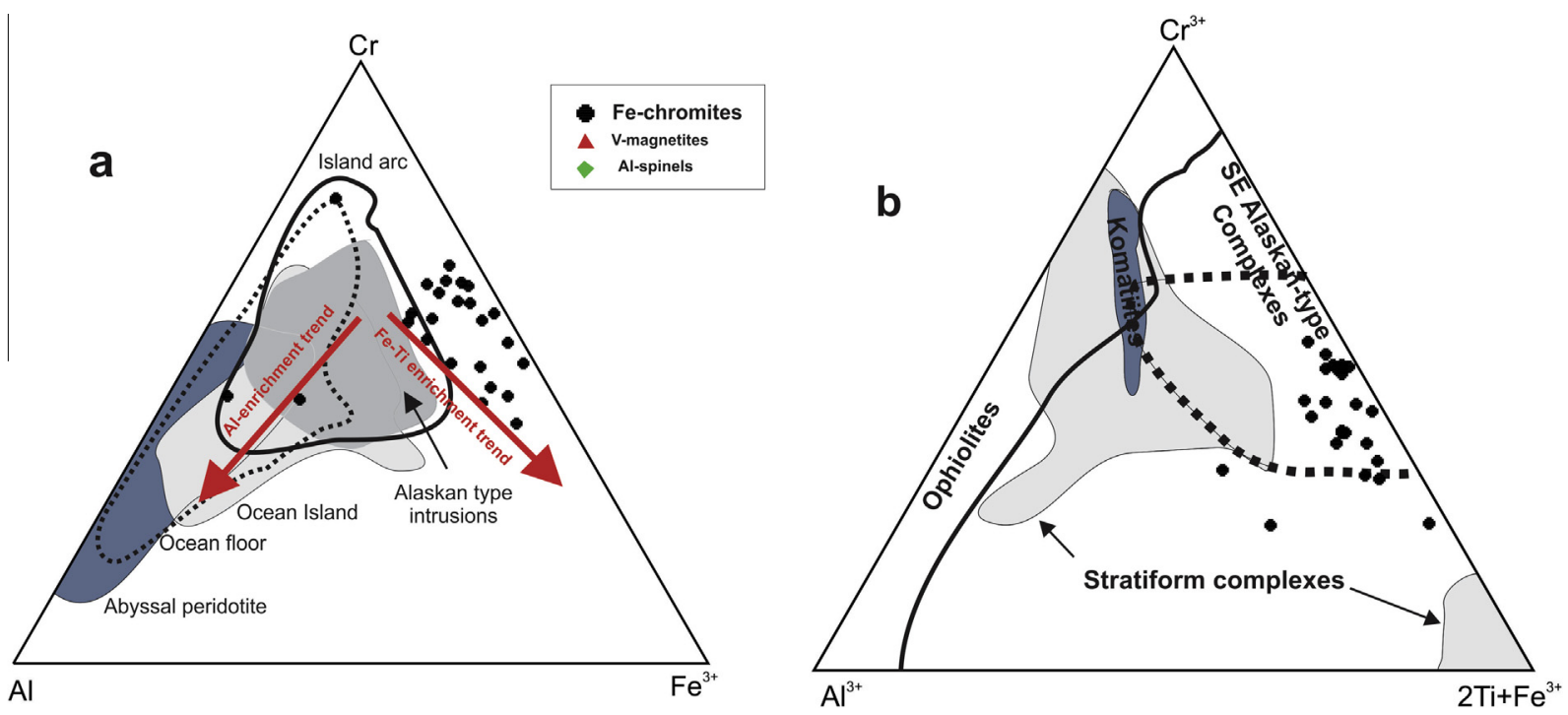

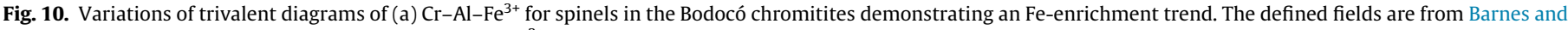

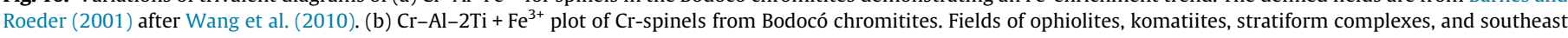
Alaskan-type complexes are from Jan and Windley (1990) after Salem et al. (2012).

\subsubsection{Spinel chemistry}

Chromites range from Fe-Chromites to $\mathrm{Cr}$-magnetites and exhibit an Fe-enrichment trend (Fig. 10a). The parent magma of Alaskan-type complexes tends to show an $\mathrm{Fe}^{3+}$ enrichment of the primary spinel, which is attributed to the oxidized nature of the arc magma (Barnes and Roeder, 2001; Ahmed et al., 2008). According to Farahat and Helmy (2006), such an increase in $\mathrm{Fe}^{3+}$ is reported from spinels of the Alaskan-type complexes and is generally absent in other igneous complexes such as ophiolites or layered intrusions. This demonstrates that the continuity in compositions from chrome-spinel to magnetite in Alaskan-type complexes reflects a combination of trapped liquid reaction and oxidation. In the same diagram, the chromites plot parallel to the island arc and Alaskantype fields and far from the OIB- and MORB-type basalt fields. As shown in Fig. 10b, the spinel compositions plotted inside the designated fields of the southeast Alaskan-type complex (Jan and Windley, 1990; Salem et al., 2012) and far from the stratiform complexes and ophiolite fields.

\subsubsection{Amphiboles}

The high $\mathrm{Mg} \#$ and the $\mathrm{TiO}_{2}$ contents of some hornblendes reinforce the inference of a primary magmatic origin, whereas a broad compositional range and negative correlation between $\mathrm{Si}$ and $\mathrm{Na}$ $+\mathrm{K}$ contents (Fig. 11a) show further similarity with most Alaskan-type and arc-cumulate complexes (e.g., Himmelberg and Loney, 1995; Pettigrew and Hattori, 2006; Su et al., 2012).

\subsubsection{Whole-rock chemistry}

Subduction-related magmas such as IAB are generally characterized by higher contents of LILE and LREE relative to HFSE and HREE (Eyuboglu et al., 2011; Kelemen et al., 2003), respectively, and negative anomalies for $\mathrm{Nb}, \mathrm{Ta}, \mathrm{Zr}, \mathrm{Hf}$, and $\mathrm{Ti}$. Moreover, this can be associated with hydrous minerals such as hornblende and biotite (Pearce, 1982; Ringwood, 1990; Hawkesworth et al., 1991; Pearce and Robinson, 2010; Eyuboglu et al., 2011).

The ultramafic and mafic members of the FMUC and BMUC cumulates are slightly enriched in LILE and LREE and depleted in HFSE and HREE. In addition, they show high positive (cumulate phases) to slight negative (mafic phases) Eu anomalies, high $\mathrm{Pb}$ anomalies (cumulate phases), and moderate negative $\mathrm{Hf}$ and $\mathrm{Zr}$ anomalies (peridotites and pyroxenites). Negative $\mathrm{Nb}$ and $\mathrm{Ta}$ anomalies are observed mainly in garnet amphibolites/garnetites.

The introduction of fluids from the subducted oceanic lithosphere including sediments may have been responsible for the enrichment in LILE and LREE (Ringwood, 1990; Hawkesworth et al., 1991).

The occurrence of ilmenite as a cumulus phase may explain the enrichment in Nb, Ta and Ti (Green and Pearson, 1987). Eyuboglu et al. (2011) also attributed the absence of negative $\mathrm{Nb}$, Ta, and Ti anomalies in some Alaskan-type intrusions to presence of ilmenite and rutile. Xiong (2006) suggested that enrichment of these elements may have occurred through the melting of rutile-bearing hydrous eclogite. Furthermore, a positive Eu anomaly in peridotites is typical in cumulate rocks, whereas the absence of conspicuous positive Eu anomalies is generally noted in gabbroic rocks. A small negative Eu anomaly in gabbroic members indicates that fractional crystallization was not a major process controlling the suppression of plagioclase and Fe-Ti oxide crystallization in the evolution of the parental magma. These combined factors may explain the absence of negative $\mathrm{Nb}, \mathrm{Ta}, \mathrm{Ti}$, and Eu anomalies (Pettigrew and Hattori, 2006; Eyuboglu et al., 2011). Further support for a subduction setting is indicated by a positive $\mathrm{Pb}$ anomaly with respect to the neighboring trace elements in peridotites, which is also present in some gabbroic members. The $\mathrm{Pb}$ anomalies are common in Alaskan-type peridotites and are better marked in subducted serpentinites and mantle wedges than in abyssal serpentinites that have experienced melt/rock interactions (Deschamps et al., 2013). The usage of relative concentrations of immobile elements is helpful in deciphering the tectonic environment for mafic and ultramafic magmatism (e.g., Pearce, 1975, 1982, 2008; Shervais, 1982; Beard, 1986; Thanh et al., 2014). In the $\mathrm{Nb} / \mathrm{Yb}-\mathrm{Th} / \mathrm{Yb}$ diagram, most gabbroic, amphibolitic and eclogitic samples plotted within the field for arc magmatic rock, except for a single sample that showed a tendency toward the MORB array (Fig. 11b). This may be indicative of a protolith derived from a metasomatized mantle source enriched by subductionrelated fluids (Pearce, 2008). These data, in combination with the LREE-enriched patterns for the FMUC and BMUC samples, suggest an arc setting.

Critical elemental ratios indicate a possible mixing between MORB magma with low $\mathrm{Ba} / \mathrm{La}, \mathrm{Ce} / \mathrm{Pb}$, and $\mathrm{La} / \mathrm{Yb}$ and arc basalt magmas with high $\mathrm{Ba} / \mathrm{La}, \mathrm{Ce} / \mathrm{Pb}, \mathrm{Zr} / \mathrm{Nb}$, and $\mathrm{La} / \mathrm{Yb}$ (Sun and McDonough, 1989; Thanh et al., 2014; Table 7). 

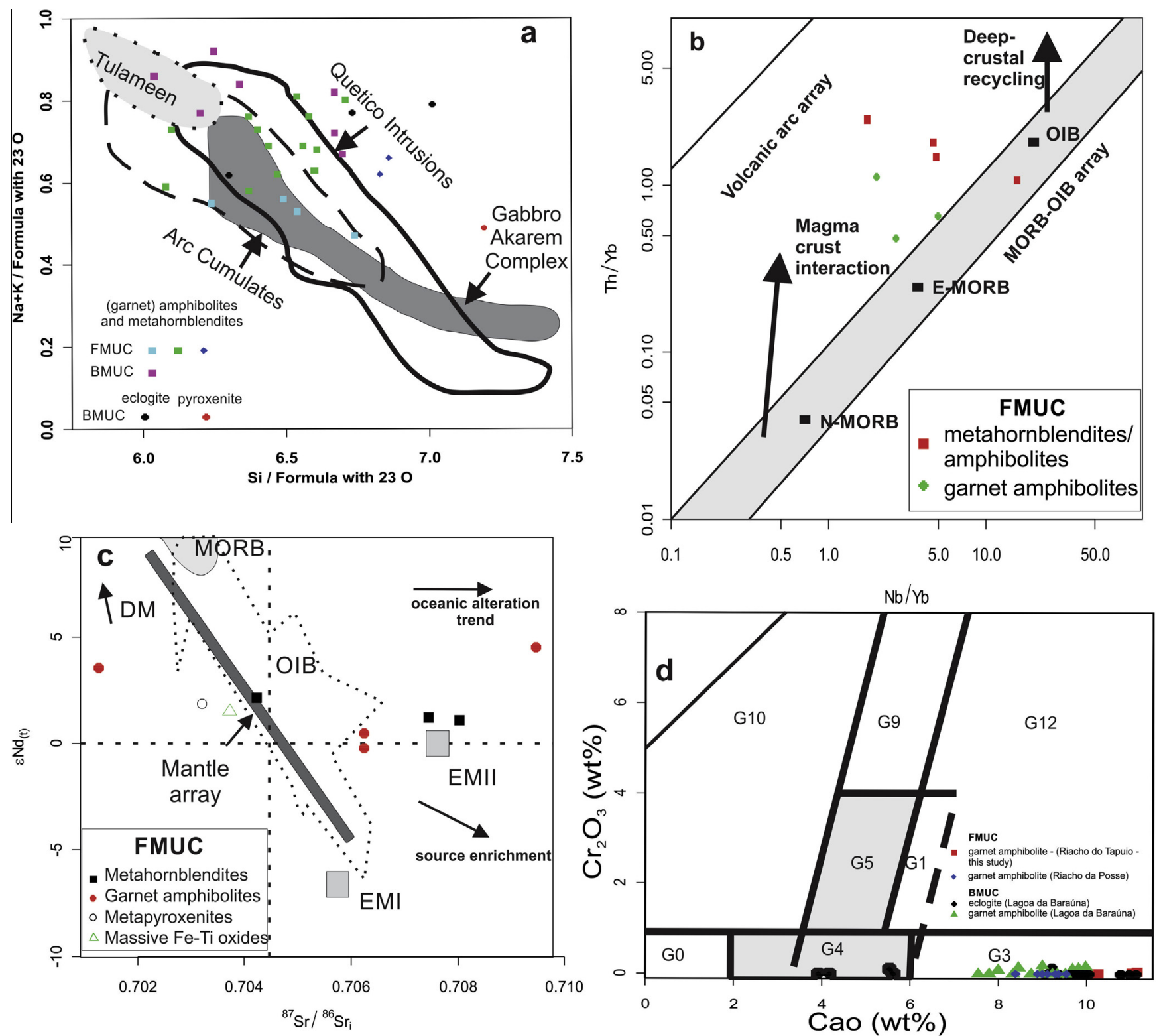

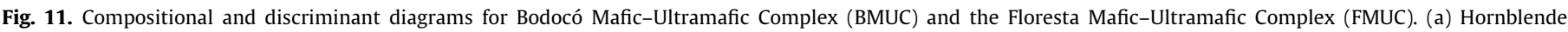

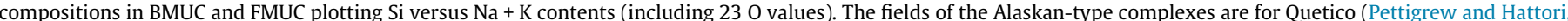

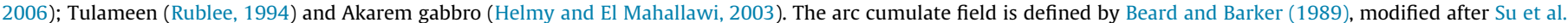

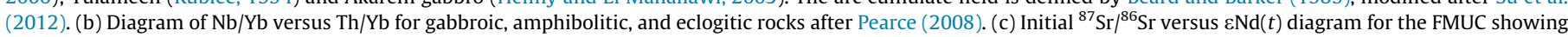

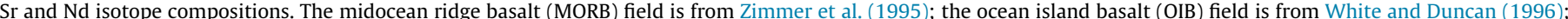

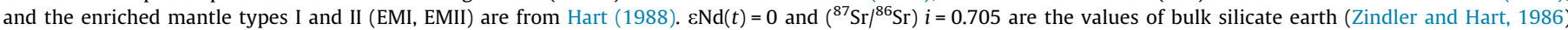

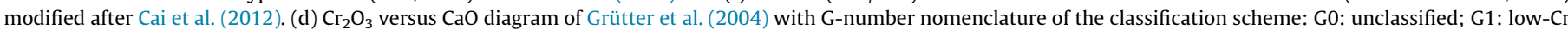
megacrysts; G3: eglogitic; G4 and G5: pyroxenitic, websteritic, and eclogitic; G9: lherzolitic; G10: harzburgitic; G12: wehrlitic.

Table 7

Average trace element ratios in the analyzed mafic rocks. Table extracted and adapted after Thanh et al. (2014) and shown for comparison.

\begin{tabular}{|c|c|c|c|c|c|c|}
\hline \multirow[t]{2}{*}{ Ratio } & \multicolumn{6}{|c|}{ Location and tectonic setting } \\
\hline & FMUC & Cao Bang (a) & N-MORB (b) & Indonesian arc (c) & Mariana (d) & Aleutian (e) \\
\hline $\mathrm{Ta} / \mathrm{Nb}$ & $0.06-0.19$ & $0.076-0.089$ & 0.06 & $0.07-0.13$ & $0.06-0.1$ & $0.06-0.39$ \\
\hline $\mathrm{Zr} / \mathrm{Nb}$ & $4.34-18.89$ & $12.56-20.87$ & 31.76 & $14-23$ & $37-86$ & $21-145$ \\
\hline $\mathrm{Ce} / \mathrm{Pb}$ & $4.58-179.67$ & $1.81-6.52$ & 25 & $3-7$ & $3.5-13.4$ & $3.16-34.39$ \\
\hline $\mathrm{Th} / \mathrm{Yb}$ & $0.48-1.79$ & $1.52-3.57$ & 0.04 & $1-4$ & $0.1-0.5$ & $0.03-0.51$ \\
\hline $\mathrm{Th} / \mathrm{Nb}$ & $0.06-0.55$ & $0.81-1.77$ & 0.05 & $0.45-1.12$ & $0.4-0.8$ & $0.08-0.83$ \\
\hline $\mathrm{Ba} / \mathrm{La}$ & $0.44-9.57$ & $4.00-22.19$ & 2.52 & $23-36$ & $22-60$ & $5.2-51.45$ \\
\hline $\mathrm{Ba} / \mathrm{Th}$ & $2.84-118.82$ & $9.06-64.41$ & 52.5 & $63-177$ & $187-674$ & $47-708$ \\
\hline $\mathrm{Sr} / \mathrm{Nd}$ & $1.86-21.69$ & $3.42-15.52$ & 12.33 & $16-44$ & $18.4-49.4$ & $13-62$ \\
\hline$(\mathrm{La} / \mathrm{Sm}) \mathrm{N}$ & $0.61-2.28$ & $2.2-2.8$ & 0.59 & $1.92-3.57$ & $0.8-1.7$ & $0.4-1.6$ \\
\hline
\end{tabular}

(a) Thanh et al. (2014); (b) Sun and McDonough (1989); (c) arc-like basalts, (d) and (e) MORB- and arc-like basalts. Floresta Mafic-Ultramafic Complex (FMUC). 


\subsection{Parental magma and mantle source}

Cr-spinel, olivine, and clinopyroxene represent early crystallization phases in FMUC and BMUC. Intercumulus minerals consist of pyroxene, magnetite, ilmenite, and hornblende. The high Mg\# of clinopyroxene at $>88$ and abundant Mg-hornblendes in primary phases suggest an Mg-rich primary liquid. According to Su et al. (2014), the high-Mg content in silicate minerals can also be attributed to crystallization of magnetite and ilmenite, which incorporates large amounts of Fe. The modal abundance of magnetite and ilmenite in the FMUC and BMUC can reach up to $20 \%$ in peridotites. The Ti content in chromites, and Fe-Ti oxides, and $\mathrm{Mg}$ bearing minerals, as earlier intercumulus/cumulus phases, calls for a high-Ti ferropicritic magma composition.

The arc tholeiitic component of the melt in the BMUC accounts for the clinopyroxene compositions, as shown in $\mathrm{Ti}+\mathrm{Cr}$ versus $\mathrm{Ca}$ map in Fig. 9d, where the data plotted in the field of orogenic basalts. Picritic or olivine tholeiite primary melt is in accordance with Alaskan-type intrusions (Irvine, 1974) with hydrous (Loucks, 1990) and arc tholeiite affinities (Helmy and El Mahallawi, 2003).

Numerous world-class Fe-Ti oxide deposits in the Panxi district and post-orogenic intrusions occurring along the Central Asian Orogenic Belt, China (CAOB) which commonly hosts Ni-Cu sulfide mineralization (Xie et al., 2014) are assigned to a ferropicritic parental magma generated by the interaction of a plume with the lithospheric mantle. The latter is enriched in eclogitic components related to subduction (Hou et al., 2012) and occurs in the Giant Hongge deposit (Bai et al., 2012). Giant Fe-Ti-V oxide layers occur in the lower and middle parts of relatively small mafic-ultramafic intrusions, as is the case of the FMUC - Serrote das Pedras Pretas mine, Riacho da Posse deposit: 54 Mt @13\% Ti and the BMUC. However, the age obtained for FMUC limits this possibility. The positive $\varepsilon N d$ values of 0.01 to 4.84 and the minor enrichment in light REEs are in agreement with an initially depleted lithospheric mantle source. The variations in $\mathrm{Sr}-\mathrm{Nd}$ isotope characteristics (Fig. 11c) suggest an isotopically-enriched lithospheric mantle reservoir close to EM-II originating from recycled oceanic crust and small amounts of subducted sediment or recycling of meltimpregnated oceanic lithosphere (Zindler and Hart, 1986; Wilson, 1989). The wide Sr isotopic variation indicates an oceanic setting, which has been widely interpreted as a subduction signature (e.g., Rollinson, 1993; Su et al., 2014). The Nd-Sr signatures and presence of hydrous minerals such as primary hornblende strengthens a setting analogous to subduction-related arc cumulates (Irvine, 1974; Himmelberg and Loney, 1995; Helmy and El Mahallawi, 2003; Farahat and Helmy, 2006; Eyuboglu et al., 2010).

The virtual absence of relics of orthopyroxene in the peridotites rules out any noteworthy crustal contamination of parental magma. The positive Eu anomaly in peridotites in some samples is consistent with their cumulate textures and also suggests insignificant crustal contamination. In contrast, in some cases, a slightly negative Eu anomaly in gabbroic members, $\mathrm{T}_{\mathrm{DM}}$ model ages $>1.6 \mathrm{Ga}$ in two samples, and inheritance of zircon aged at $\sim 1.9 \mathrm{Ga}$ may attest to an involvement of a crustal source in the genesis.

These factors indicate derivation of high-Ti ferropicritic parental magma from a depleted mantle source that has undergone metasomatism in a subduction setting.

\subsection{Metamorphism}

A similar metamorphic evolution for FMUC and BMUC can be established on the basis of almost identical paragenetic and textural attributes related to retrograde metamorphism (Beurlen et al., 1992). In both complexes, a magmatic mineral assemblage is represented by olivine $\pm \mathrm{Cr}$-spinel \pm clinopyroxene \pm magnetite \pm ilmenite \pm apatite \pm sulfides $? \pm$ plagioclase $? \pm$ hornblende. A preeclogitic metamorphic stage was suggested by Beurlen et al. (1992) on the basis of the record of well-foliated, fine-grained snow-ball texture inclusions in garnet porphyroblasts. This stage has the mineral assemblage of rutile + epidote + amphibole + plagioclase. A high-pressure stage has omphacite preserved in the BMUC (Beurlen et al., 1992) \pm rutile \pm (clino)zoisite \pm garnet, with a consistent bulk composition similar to garnets from eclogites within glaucophane schists and a small component showing a granulitic trend (Fig. 11d). According to Beurlen et al. (1992), high-pressure metamorphism is supported for the BMUC based on the jadeite content of omphacite/clinopyroxene, the Fe/Mg partitioning between omphacite/clinopyroxene and garnet, the Si activity in phengite, and the Na content of amphiboles in retrograde symplectites in gabbroic members, which suggests a progressive metamorphic evolution up to C-type eclogites (Coleman et al., 1965) at $13 \mathrm{kbar} / 525^{\circ} \mathrm{C}$. This was followed by a retrograde path of medium pressure $(\mathrm{P}) / \mathrm{T}$ ratio between $10 \mathrm{kbar} / 680^{\circ} \mathrm{C}$ and $7-5 \mathrm{kbar} / 450{ }^{\circ} \mathrm{C}$, as estimated by the Si activity in the phengite, and the empirical comparison of the amphibole composition, which ranges from barroisitic to sodic Mg-hornblendes to the greenschist facies (see Inline Supplementary Fig. S2).

Sodic-calcic amphibole and almandine-pyrope garnets indicate blueschist metamorphic conditions. Tschermakitic amphibole and Fe-barroisite found in the coronas surrounding the garnets from the BMUC and as grains in the FMUC (Supplementary Table 2) can be attributed to the early stages of retrograde metamorphism derived from omphacites (Deer et al., 1966) and relics of blueschist metamorphic facies, respectively. Thus, in addition to their similarity in terms of their retrogressive high-pressure metamorphic evolution, the FMUC and BMUC are correlated by their high Ti/Fe ratios in massive ores associated with ultramafic rocks, the same gabbroic intercalations composed of only garnet and amphibole with the same mineral compositions, the absence of plagioclase, and the abundance of rutile (Beurlen et al., 1992; Beurlen and Villarroel, 1990; Beurlen, 1988; this study).

\subsubsection{Subsolidus exsolution of Fe-Ti solid solutions}

Ilmenite-magnetite geothermobarometry, based on the geothermometer of Andersen and Lindsley (1985) helped to calculate $\mathrm{O}$ fugacities and the possible $\mathrm{Fe}-\mathrm{Ti}$ oxide blocking temperatures of subsolidus equilibration. These values are listed in Supplementary Table 1 and are plotted in a temperature versus $\log \mathrm{fO}_{2}$ diagram in Fig. 12a. The calculated $\mathrm{O}$ fugacity values obtained for the ilmenite-magnetite coexistent couples vary from $\sim 10^{-21.04}$ to $\sim 10^{-18.26}$ and plotted as a nickel-nickel-oxide (NNO) curve, similar to arc cumulates/Alaskan-type complexes (Himmelberg and Loney, 1995). The blocking temperatures of subsolidus equilibration range from 573 to $506{ }^{\circ} \mathrm{C}$. It should be noted that these blocking temperatures, obtained on the basis of the magnetite-ilmenite intergrowths, are significantly lower than the early crystallization temperatures of ilmenite and magnetite from Alaskan-type intrusions above $815^{\circ} \mathrm{C}$ (Himmelberg and Loney, 1995). However, owing to sub-solidus cation exchange and reequilibration during high pressure metamorphism and the influx of new fluids driven by subduction-related processes or by granitic intrusion (Riacho do Icó Suite wall rock), the calculated temperatures should be taken as minimum temperatures for these modifications rather than crystallization. For the sake of clarity, the ulvöspinel contents in the magnetite, calculated by using the method of Stormer (1983), are below $1.7 \mathrm{~mol} \%$, which is in accordance with the near absence of fine trellis intergrowths in magnetite crystals. The end member component $\left(\mathrm{X}_{\mathrm{Ilm}}\right)$ of the analyzed ilmenite is almost pure, at $>92.41 \%$ mole. These textural features show that the magnetite lost almost all of its Ti to its surroundings through solid-state diffusion, which contributed to the 

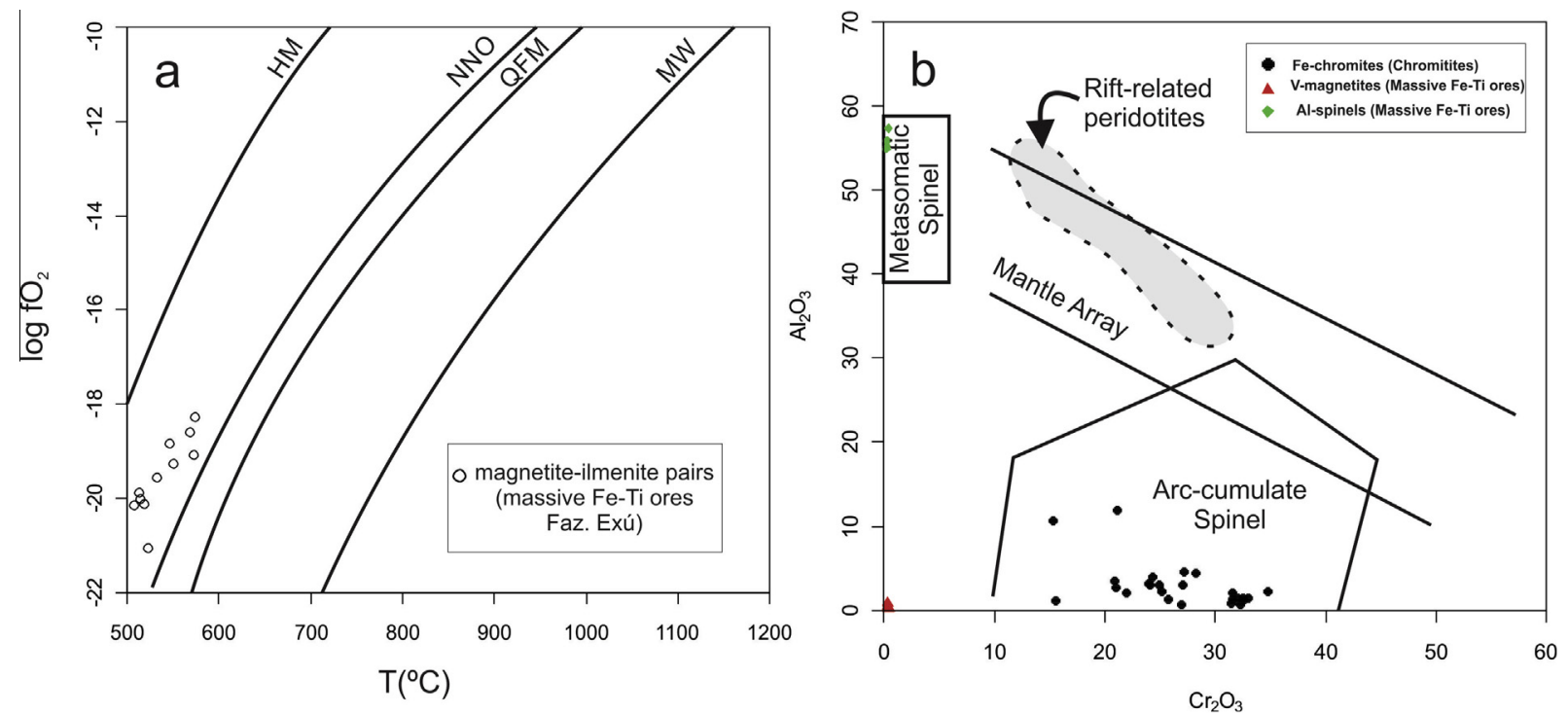

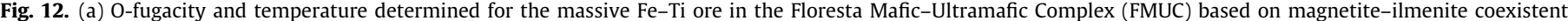

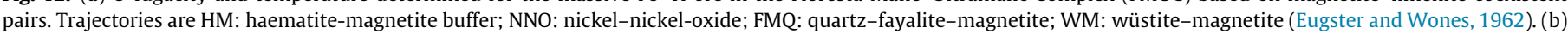
$\mathrm{Al}_{2} \mathrm{O}_{3}$ versus $\mathrm{Cr}_{2} \mathrm{O}_{3}$ (wt.\%) diagram of Franz and Wirth (2000) after Seo et al. (2013).

formation of new granular ilmenite and enhanced the quality of the ore. Moreover, the presence of interstitial Al-spinels surrounding the magnetite and ilmenite indicate complete exsolution by cooling temperature and exchange of $\mathrm{Fe}$ and $\mathrm{Ti}$ with $\mathrm{Al}$, underlining a metasomatic origin (Fig. 12b). Outside of the granites, these changes do not appear to have affected the Fe-chromites of the BMUC, which remained unscathed and plotted along arc cumulate spinels distinctly far from rift-cumulate spinel fields (Fig. 12b). The occurrence of cumulus magnetite and ilmenite as the oxide phases suggests that the magma from which the ultramafic rocks crystallized was rich in $\mathrm{Fe}_{2} \mathrm{O}_{3}$ and $\mathrm{H}_{2} \mathrm{O}$. Considering its crystallization after clinopyroxene but before hornblende, the oxidation conditions of the magma at the time of crystallization were similar to those reported for arc-basalt ultramafic xenoliths (Conrad and Kay, 1984) with mineral assemblages that were similar to Alaskan-type ultramafic rocks (Himmelberg and Loney, 1995) and at least as high as the NNO buffer (Helz, 1973).

In summary, ilmenite growth is an unfavorable phase in the eclogitic rocks where rutile is the most common accessory phase (Force, 1991). Thus, we cannot discard late magmatic fluids as a mechanism for the enrichment of proto-ore mineralization inside the granite, as suggested by fluid/rock interactions observed in the mines (Fig. 13a and b). Therefore, only the deposits within the Riacho do Icó Suite have economic value. We infer that some $\mathrm{Fe}-\mathrm{Ti}$ ore lenses and ultramafic proto-ore probably reequilibrated under new water/fluid content and $\mathrm{O}$ fugacity conditions, increasing their Ti/Fe ratios substantially by fluids from the Riacho do Icó granitic intrusion. Previously, secondary enrichment was represented by rutile growth up to $12 \%$ during high-pressure/ low-temperature metamorphism.

\section{Geodynamic significance and concluding remarks}

The crystallization age for the FMUC, also known as the Serrote das Pedras Pretas Suite, has been constrained at ca. 1025 Ma with $\varepsilon \mathrm{Nd}(t)$ of 2.1. This confirms a mafic-ultramafic accretionary juvenile event where such intrusions are considered to be slightly older than other rocks from the Cariris Velhos event (e.g., Kozuch, 2003; Santos et al., 2010; Van Schmus et al., 2011). Preferentially, the emplacement of Alaskan-type intrusions occurred close to the end of subduction and prior to the accretion-collision of terranes (Pettigrew and Hattori, 2006; Su et al., 2012).
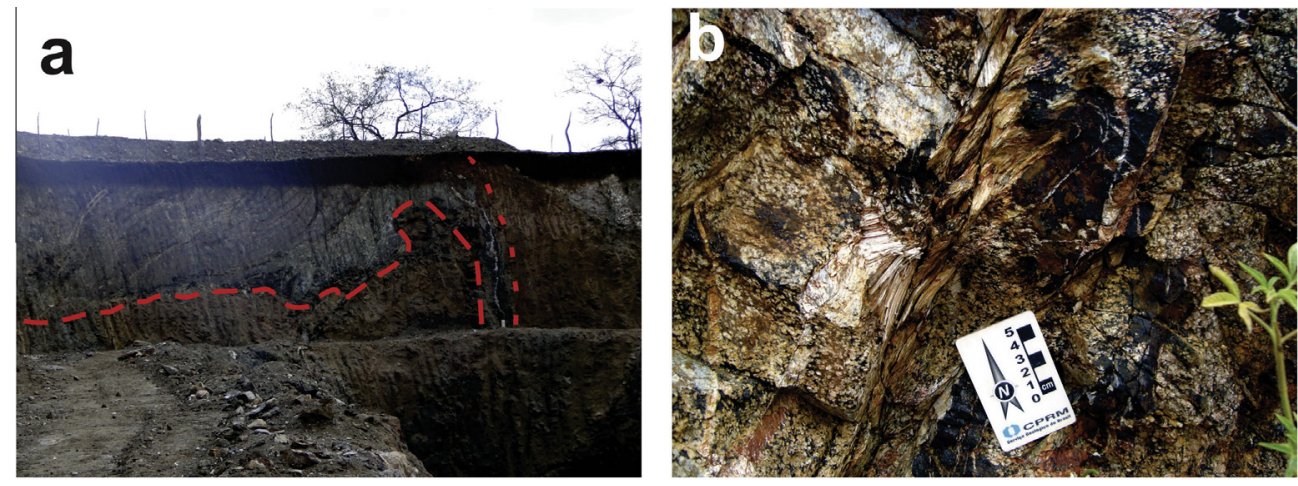

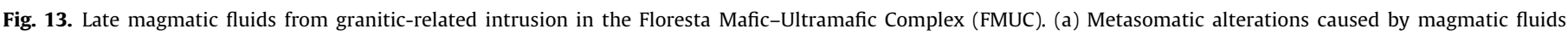

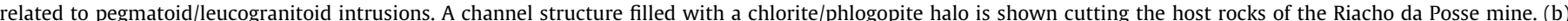

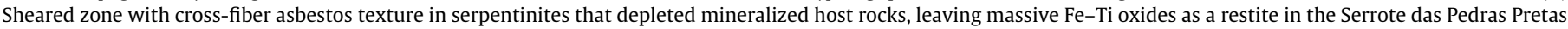
mine. 
A closer and analogous Mesoproterozoic ( $980-960 \mathrm{Ma})$ continental arc is developed on the southern margin of the Paleoproterozoic Pernambuco-Alagoas Domain (PEAL) including the intruded $\sim 950$ Ma post-tectonic Serra Negra granite (Oliveira et al., 2010). The age of the FMUC corroborates the possibility that at least this complex does not refer to the end of subduction related to this Tonian event. The recent discovery of the Sítio do Icó metavolcanic rock, originated from high-Mg magma with a chemical signature similar to an andesitic composition at $1005 \pm 5$ Ma (Lages et al., 2014; Guimarães et al., 2015), is consistent with these ultramaficmafic assemblages that resemble cumulates from hydrous, high$\mathrm{Mg}$ basaltic magmas having andesitic lavas as the complementary liquid fraction (Murray, 1972; Garuti, 2011).

The FMUC rocks could have originated from igneous accumulation from hydrous magma likely at shallow depth owing to the high amounts of ilmenite and magnetite as early cumulus phases, and they were emplaced along a major fault zone or in a spreading center. In contrast, the content of $\mathrm{Ni}-\mathrm{Cu}$ sulfide disseminations in Neoproterozoic arcs should remit to a deeper level of the arc, where it could remain as a magma chamber crystallizing at the base of an arc system (Helmy et al., 2014).

Considering the older ages of $\sim 995$ Ma obtained for volcanic and gneissic rocks in this part (Santos et al., 2010; Brasilino et al., 2014), the FMUC likely represents magma that formed in a primitive extensional environment prior to the formation of a mature arc sequence in the southwesternmost part of the terrane. Their Sm/Nd values are typical of mafic and ultramafic rocks of primitive arc and oceanic crust fragments.

Hence, during active subduction, arc detritus likely accumulated in a back-arc/intra-arc basin, forming the São Caetano sequence. In contrast, the FMUC constitutes the basement in a proto-arc environment.

On the other hands, the BMUC occurs along the border with the Paleoproterozoic Icaiçara fragment surrounded by Tonian sedimentary sequences. Presently, this is recognized as an allochthonous fragment that could have been formed through accretion of a microcontinent or as part of a disrupted continental margin.

The BMUC has the most robust criteria for classification as a deeper root of the island arc such as clinopyroxene and Fe-chromite chemistry. However, geochronological studies are needed to constrain their ages to confirm whether these rocks are slight younger than those of the FMUC.

The BMUC and FMUC may represent subduction-related magmatism, either prior to or even synchronous to the juxtaposition of the juvenile island arc with the Pernambuco-Alagoas or Alto Moxotó domains as possible terranes.

The arc affinity of metasedimentary rocks in the central and north-northeastern parts of the Alto Pajeú Domain is indicated by the geochemical signatures of metamorphosed greywackes, and lithic and arkose sandstones, which are characteristics of derivation from island arc and/or continental arc sources (Sales et al., 2011) and sources mixed with volcanogenic derivatives of mafic and intermediate igneous rocks (Santos, 1995; Kozuch, 2003; Medeiros, 2004; Santos et al., 2010).

Moreover, other samples such augen-gneisses and migmatitic facies are classified as calc-alkaline to high-K calc-alkaline, which are compatible with both continental arc and syn-to-late collisional signatures (Jardim de Sá, 1994; Santos, 1995; Santos and Medeiros, 1999; Kozuch, 2003; Medeiros, 2004; Santos et al., 2010). However, many augen-gneisses have chemical characteristics compatible with an extension-related setting with the generation of A-type granites (Guimarães et al., 2015; Neves, 2003) or A-type post-collisional granites (Cruz et al., 2014). These A-type granitoids and the absence of evidence of Tonian metamorphism can be used to argue against a continental margin-magmatic arc tectonic setting. We detected a unique zircon with low Th/U yielding a discordant Tonian age. However, this assumption requires significantly more data; thus, the debate on the continental collision remains open. Moreover, evidence of a complete arc sequence development during the Cariris Velhos event is indicated. Therefore, based on the most reliable arc chemistry signatures, the ages can determined by volcanic arc magmatism until $995 \mathrm{Ma}$ from the appearance of extension-related plutonism, which is always younger than $975 \mathrm{Ma}$. These granitic intrusions could be post-collisional or even post-tectonic.

Some authors have suggested the development of a back-arc or fore-arc basin adjacent to a subduction zone (Santos, 1995; Kozuch, 2003; Santos et al., 2010; Sales et al., 2011). This theory is supported by the geochemical patterns of non-cumulate metamafic rocks from the FMUC, which are similar to tholeiitic series mixing between arc and MORB/back-arc settings.

Preserved relics of oceanic crust of Monte Orebe (Moraes, 1992) formed between the São Francisco Craton and the PEAL, far less than $200 \mathrm{~km}$ of the BMUC and $380 \mathrm{~km}$ of the FMUC, suggest the development of a young oceanic floor between the intervening Borborema Province and the São Francisco Craton at ca. $820 \mathrm{Ma}$ (de Caxito et al., 2014b).

During the western Gondwana amalgamation, a large Himalayan-scale collisional orogeny (Araújo et al., 2014a,b) converged the craton blocks and consumed the large Goiás-Pharusian Ocean defined by relics of eclogitic and granulitic rocks at ca. 615589 Ma (Amaral, 2010; Amaral et al., 2012; Santos et al., 2014a; Araújo et al., 2014a) in the Ceará Central Domain. These rocks roughly align with other HP and ulta-HP (UHP) rocks in Africa dated at c. 620-610 Ma (Bernard-Griffiths et al., 1991; Affaton et al., 2000; Jahn et al., 2001; Araújo et al., 2014a).

High-pressure metamorphism is recorded in the BMUC, whereas retrogressed phases are present in FMUC outcrops. The $\mathrm{U}-\mathrm{Pb}$ zircon on the metamorphic overgrowth rims on FMUC rock samples yielded a younger Concordia age of $625 \pm 6 \mathrm{Ma}$. This value is compatible with the metamorphic peak of the eclogitic or a highgrade (such as granulite) progressive stage for the Pan-AfricanBrasiliano event. We argue that these retrogressions of eclogitic rocks occurred in a western Gondwanan tectonic context, and that they could be associated with the closure of a branch of a Neoproterozoic ocean basin between and along the southern and southwestern borders of the Alto Pajeú and Piancó-Alto Brigida domains and Alto Moxotó and Pernambuco-Alagoas domains, probably correlating east of the Central African fold belt (Van Schmus et al., 2008).

In the beginning of a subduction event, the overlying plate and the subducting plate are not fully decoupled (Xie et al., 2013). With progressive hydration of the mantle wedge, the overlying plate is thinned by thermal flux. This process may have been responsible for the thermal erosion of the arc root-subarc mantle when considering a vigorous mantle corner flow to drag the subarc mantle peridotite into the subduction channel (Arcay et al., 2007; Hattori et al., 2010). The rapid addition of water could have produced the meltprecipitated zircons with older overgrowth rims at $685 \pm 17 \mathrm{Ma}$, which may be attributed to the initial stages of subduction.

In summary, in our hypothetical scenario (Fig. 14), the generation of these mafic-ultramafic complexes was coeval with island arc volcanism and syn-orogenic sedimentation. Such a scenario can best be interpreted as a proto-to-marginal arc-back-arc system that evolved between 1025 and $995 \mathrm{Ma}$ which its extension could have occurred until $975 \mathrm{Ma}$. Such a scenario can indicate a mature arc or even arc-roots. The arc cumulate complexes (FMUC) were emplaced at ca. $1025 \mathrm{Ma}$ as a basement of a proto-arc upon which the Cariris Velhos arc was built. The BMUC rocks and their geodynamic interpretation as the roots of an arc coupled with stillpremature evidence of metamorphism could indicate the beginning of an arc accretion/collisional stage; however, this inference 


\section{a) Proto-arc spreading (1025 Ma)}

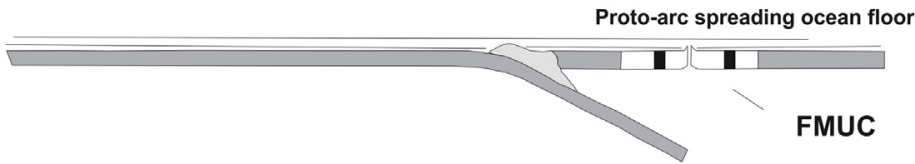

b) Establishment of mature Cariris Velhos arc (<1025 Ma - $995 \mathrm{Ma}$ )
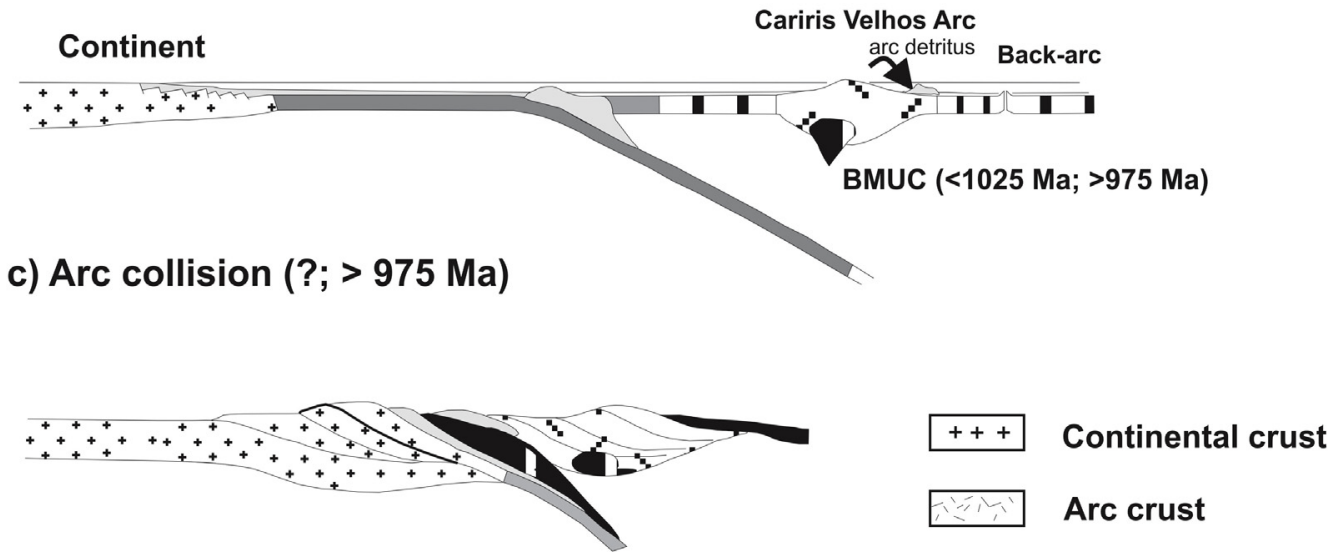

Arc crust

Sediments

d) Post-collisional extension ( $<975 \mathrm{Ma}$ )
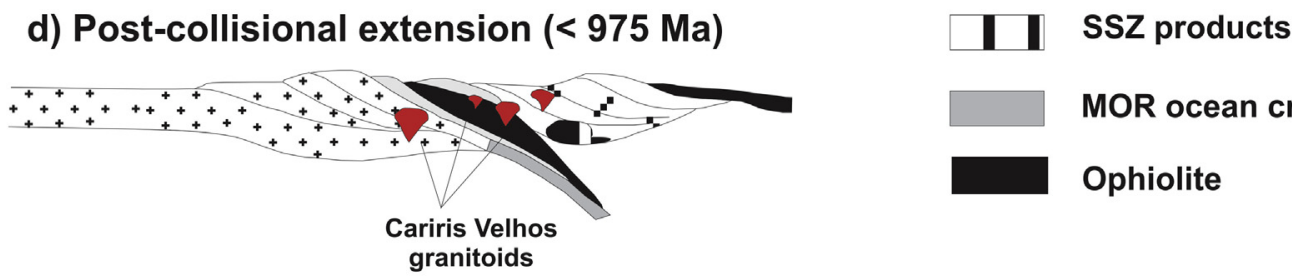

MOR ocean crust

Ophiolite

\section{e) W. Gondwana Oceanic stage} ca. 820-650 Ma

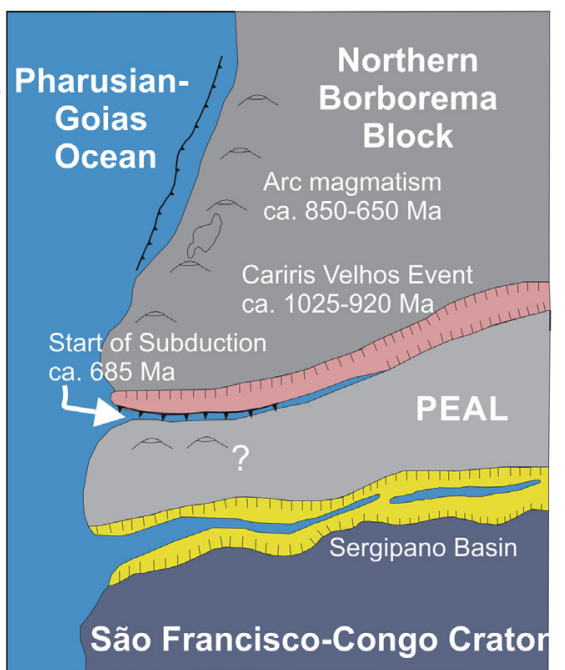

\section{f) W. Gondwana Collisional stage} ca. $625-600 \mathrm{Ma}$

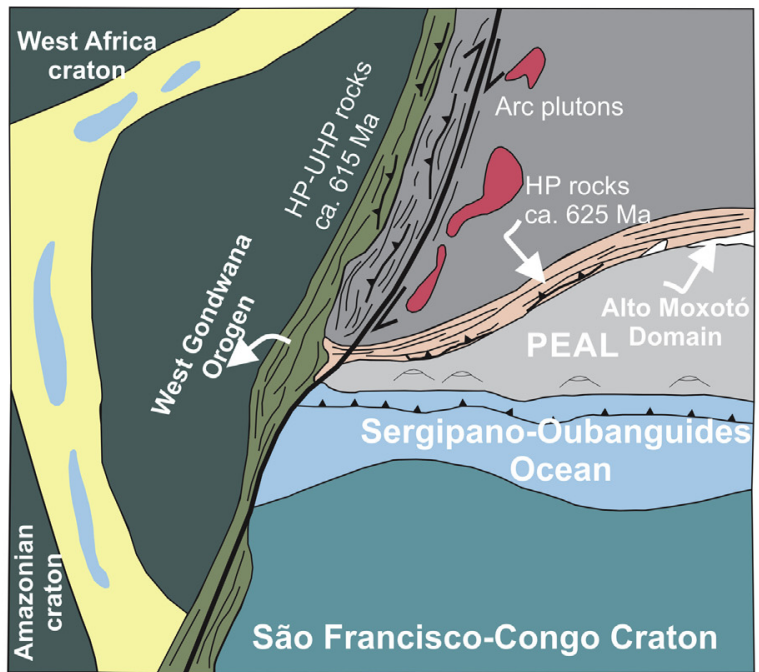

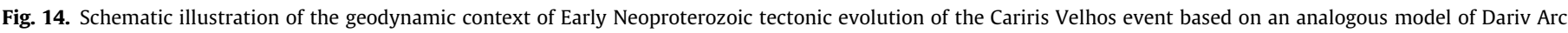

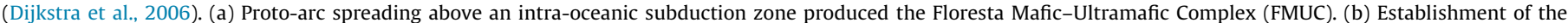

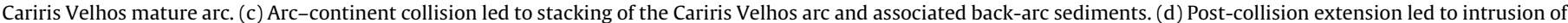

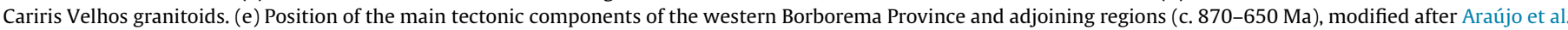

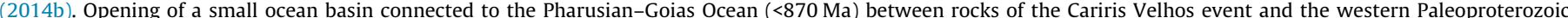

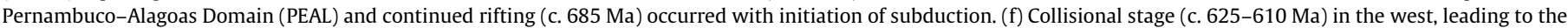

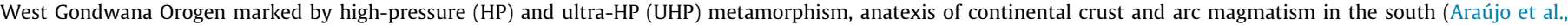
$2014 \mathrm{~b}$ and references therein). The small ocean branch along the rocks of the Cariris Velhos event collided first, according to the HP metamorphic peak at c. $625 \mathrm{Ma}$ 
requires further substantiation. Indeed, the majority of the Tonian orthogneisses in the Transversal Zone intruded after 975 Ma and have predominantly A-type chemical signatures, although also occur a transition between calc-alkaline and high-K calc-alkaline. We can infer a post-collisional or even a post-tectonic stage for these orthogneisses. The granitic intrusions and emplacement of more bimodal volcanic rocks ended at ca. $920 \mathrm{Ma}$.

Evidence of ocean crust and extension-related magmatism occurred at ca. 820 Ma.

The onset of the next subduction was initiated by westward convergence, which could have caused thermal erosion and delamination by dragging the arc root pieces into the subduction channel at $685 \mathrm{Ma}$. A short loop of these rocks in the eclogitic condition of $<14$ kbar reached the metamorphic peak at ca. $625 \mathrm{Ma}$, from which it was exhumed along with granitic materials and sediments.

Finally, we conclude that the high Ti/Fe ratios in the FMUC economic ore bodies are attributed to the early stages of accumulation from an enriched source in part from the Ti partitioning between silicate and oxide phases, with rutile mineral enrichment up to $12 \%$ under eclogitic conditions. After that time, the Ti enrichment occurred through hydrothermal magmatic fluids within the granitic wall rock.

\section{Acknowledgements}

The authors would like to thank CPRM - Geological Survey of Brazil for financial support and UnB for the use of its isotopic facilities. GAL is grateful to Professor Manoj K. Pandit for offering informal help that substantially improved the early draft of this manuscript. ELD is thankful to the financial support of the Brazilian National Research Council (CNPq) for the grant 454272/2014-6 and 308312/2014-7. Prof. Wilson Teixeira, the associate editor, and anonymous reviewers are thanked for providing constructive comments.

\section{Appendix A. Supplementary data}

Supplementary new data (Tables $1-4$ ) and recalculated existent data (Appendices A-D) associated with this article can be found in the online version., at http://dx.doi.org/10.1016/j.precamres.2016. 04.017.

\section{References}

Abd El-Rahman, Y., Helmy, H.M., Shibata, T., Yoshikawa, M., Arai, S., Tamura, A., 2012. Mineral chemistry of the Neoproterozoic Alaskan-type Akarem Intrusion with special emphasis on amphibole: implications for the pluton origin and evolution of subduction-related magma. Lithos 155, 410-425.

Affaton, P., Kröner, A., Seddoh, K.F., 2000. Pan-African granulite formation in the Kabye Massif of northern Togo (West Africa): Pb-Pb zircon ages. Int. J. Earth Sci. $88,778-790$.

Ahmed, A.H., Helmy, H.M., Arai, S., Yoshikawa, M., 2008. Magmatic unmixing in spinel from late Precambrian concentrically-zoned mafic-ultramafic intrusions, Eastern Desert, Egypt. Lithos 104, 85-98.

Almeida de, F.F.M., Hasui, Y., Brito Neves, B.B., Fuck, R.A., 1981. Brazilian structural provinces: an introduction. Earth Sci. Rev. 17, 1-21.

Amaral, W.S., 2010. Analise geoquímica, geocronológica e geotermobarométrica das rochas de alto grau metamórfico adjacentes ao arco magmático de Santa Quitéria, NW da Província Borborema (Ph.D. thesis). Universidade Estadual de Campinas, p. 210.

Amaral, W.S., Santos, T.J.S., Wernick, E., Nogueira Neto, J.A., Dantas, E.L., Matteini, M., 2012. High-pressure granulites from Cariré, Borborema Province, NE Brazil: tectonic setting, metamorphic conditions and $\mathrm{U}-\mathrm{Pb}, \mathrm{Lu}-\mathrm{Hf}$ and $\mathrm{Sm}-\mathrm{Nd}$ geochronology. Gondwana Res. 22, 892-909.

Andersen, D.J., Lindsley, D.H., 1985. New (and final!) Models for the Ti-Magnetite/ Ilmenite Geothermometer and Oxygen Barometer. Abstract AGU 1985 Spring Meeting Eos Transactions. American Geophysical Union, pp. 66-416.

De Araújo, C.E.G., Rubatto, D., Hermann, J., Cordani, U.G., Caby, R., Basei, M.A.S., 2014a. Ediacaran 2,500-km-long synchronous deep continental subduction in the West Gondwana Orogen. Nat. Commun. 5, 1-8.

Araújo, C.E.G., Weinberg, R.F., Cordani, U.G., 2014b. Extruding the Borborema Province (NE-Brazil): a two-stage Neoproterozoic collision process. Terra Nova 26 (2), 157-168.
Arcay, D., Tric, E., Doin, M.P., 2007. Slab surface temperature in subduction zones: influence of the interplate decoupling depth and upper plate thinning processes. Earth Planet. Sci. Lett. 255, 324-338.

Bai, Z., Zhong, H., Naldrett, A.J., Zhu, W., Xu, G., 2012. Whole-rock and mineral composition constraints on the genesis of the giant Hongge $\mathrm{Fe}-\mathrm{Ti}-\mathrm{V}$ oxide deposit in the Emeishan large igneous Province, Southwest China. Econ. Geol. 107, 507-524.

Barnes, S.J., Roeder, P.L., 2001. The range of spinel compositions in terrestrial Mafic and ultramafic rocks. J. Petrol. 42, 2279-2302.

Beard, J.S., 1986. Characteristic mineralogy of arc-related cumulate gabbros: implications for the tectonic setting of gabbroic plutons and for andesite genesis. Geology 14, 848-851.

Beard, J.S., Barker, F., 1989. Petrology and tectonic significance of gabbros, tonalities shoshonites, and anorthosites in a late Paleozoic arc-root complex in the Wrangellia terrane, southern Alaska. J. Geol. 97, 667-683.

Bernard-Griffiths, J., Peucat, J.-J., Menot, R.-P., 1991. Isotopic Rb-Sr, U-Pb and Sm$\mathrm{Nd}$ and trace element geochemistry of eclogites from the PanAfrican belt: a case study of REE fractionation during high-grade metamorphism. Lithos 27 43-57.

Beurlen, H., 1988. Fazenda Esperança (Bodocó) e Riacho da Posse (Floresta): Duas ocorrências atípicas de Fe-Ti no Estado de Pernambuco (Post-doctoral thesis). Universidade Federal de Pernambuco, p. 88

Beurlen, H., Villarroel, S., 1990. Petrografia de duas ocorrências de provável eclogito em Bodocó e Floresta no estado de Pernambuco, Brasil. Rev. Bras. Geociênc. 20 $111-121$.

Beurlen, H., Da Silva, A.F., Guimarães, I.P., Brito, S.B., 1992. Proterozoic C-type eclogites hosting unusual $\mathrm{Ti}-\mathrm{Fe}-\mathrm{Cr}-\mathrm{Cu}$ mineralization in northeastern Brazil. Precambrian Res. 58, 195-214.

Brasilino, R.G., Miranda, A.W.A., Morais, D.M.F., de Lages, G.A., 2014. Programa Geologia do Brasil. Carta Geológica Escala 1:100.000: Folha Mirandiba SC.24-XA-I. CPRM/Serviço Geológico do Brasil. Available on <http://geobank.cprm.gov. br/pls/publico/geobank.documents.open_zipfile?id_sessao=20160326193401\& file=mirandiba.zip $>$ in 03/26/2016.

Brito, M.F.L., Cruz, R.F., 2009. O Complexo Metavulcanossedimentar da região de Salgueiro/PE, Zona Transversal, Província Borborema, NE do Brasil. In: SBG Simpósio de Geologia do Nordeste, 24. Fortaleza. Anais. pp. 201.

Brito Neves, B.B., 1983. O Mapa Geológico do Nordeste Oriental do Brasil, Escala 1:1 000000. Tese de Livre Docência, Instituto de Geociências da Univ. de S. Paulo, p. 171.

Brito Neves, B.B., Van Schmus, W.R., Santos, E.J., Campos Neto, M.C.C., 1995. O Evento Cariris Velhos na Província Borborema: integração de dados, implicações e perspectivas. Rev. Bras. Geociênc. 25, 151-182.

Brito Neves, B.B., Santos, E.J., Van Schmus, W.R., 2000. Tectonic history of the Borborema Province. In: Cordani, U.G. et al. (Eds.), Tectonic Evolution of the South America, 31st International Geological Congress, pp. 151-182.

Brito Neves, B.B., Campos Neto, M.C.C., Van Schmus, W.R., Santos, E.J., 2001a. O Sistema Pajeú-Paraíba e o Maciço São José do Campestre no Leste da Borborema. Rev. Bras. Geociênc. 31, 173-184.

Brito Neves, B.B., Campos Neto, M.C.C., Van Schmus, W.R., Fernandes, M.G.G., Souza, S.L., 2001b. O Terreno Alto Moxotó no Leste da Paraíba (Maciço Caldas Brandão) Rev. Bras, Geocic. 31, 185-194.

Brito Neves, B.B., Van Schmus, W.R., Kozuch, M., Santos, E.J., Petronilho, L., 2005. A Zona Tectônica Teixeira Terra Nova - ZTTTN - fundamentos da Geologia Regional e Isotópica. Revista do Instituto de Geociências - USP. Série Cientifica $5,57-80$.

Brügmann, G.E., Reischmann, T., Naldrett, A.J., Sutcliffe, R.H., 1997. Roots of an Archean volcanic arc complex: the Lac des Iles area in Ontario, Canada. Precambrian Res. 81, 223-239.

Bühn, B.M., Pimentel, M.M., Matteini, M., Dantas, E.L., 2009. High spatial resolution analysis of $\mathrm{Pb}$ and $\mathrm{U}$ isotopes for geochronology by laser ablation multicollector inductively coupled plasma mass spectrometry (LA-MC-ICP-MS. An. Acad. Bras. Ciênc. 81, 1-16.

Caby, R., Sial, A.N., Arthaud, M., Vauchez, A., 1991. Crustal evolution and the Brasiliano orogeny in Northeast Brazil. In: Dallmeyer, R.D., Lecorché, P. (Eds.) The West African Orogens and Circum-Atlantic Correlatives. Springer-Verlag, pp. 373-397.

Cai, K., Sun, M., Yuan, C., Zhao, G., Xiao, W., Long, X., 2012. Keketuohai maficultramafic complex in the Chinese Altai, NW China: Petrogenesis and geodynamic significance. Chem. Geol. 294-295, 26-41.

Chen, B., Suzuki, K., Tian, W., Jahn, B.M., Ireland, T., 2009. Geochemistry and Os-Nd$\mathrm{Sr}$ isotopes of the Gaositai Alaskan-type ultramafic complex from northern North China Craton: implications for mantle-crust interaction. Contrib. Mineral. Petrol. 158, 683-702.

Coleman, R.G., 1971. Plate tectonic emplacement of upper mantle peridotites along continental edges. J. Geophys. Res. 76, 1212-1222.

Coleman, R.G., Lee, D.E., Beatty, L.B., Brannock, W.W., 1965. Geological Society of America Bulletin Eclogites and Eclogites: their differences and similarities. Geol Soc. Am. Bull. 76, 483-508.

Conrad, W.K., Kay, R.W., 1984. Ultramafic and mafic inclusions from Adak Island: crystallization history, and implications for the nature of primary magmas and crustal evolution in the Aleutian arc. J. Petrol. 25, 88-125.

Corfu, F., Hanchar, M., Hoskin, P.W.O., Kinny, P., 2003. Atlas of zircon textures. Rev. Mineral. Geochem. 53 (1), 469-500.

Corsini, M., Vauchez, A., Archanjo, C.J., 1991. Strain transfer at continental scale from a transcurrent shear zone to a transpressional fold belt: the Patos-Serido system, Northeastern Brazil. Geology 19, 586-589. 
Cruz, R.F., Pimentel, M.M., Accioly, A.C.A., Rodrigues, J.B., 2014. Geological and isotopic characteristics of granites from the Western Pernambuco-Alagoas Domain: implications for the crustal evolution of the Neoproterozoic Borborema Province. Braz. J. Geol. 44, 627-652.

de Caxito, F.A., Uhlein, A., Dantas, E.L., 2014a. The Afeição augen-gneiss Suite and the record of the Cariris Velhos Orogeny (1000-960 Ma) within the Riacho do Pontal fold belt, NE Brazil. J. S. Am. Earth Sci. 51, 12-27.

Caxito, F., Uhlein, A., Stevenson, R., Uhlein, G.J., 2014b. Neoproterozoic oceanic crust remnants in northeast Brazil. Geology 42, 387-390.

DeBari, S.M., Coleman, R.G., 1989. Examination of the deep levels of an island arc: evidence from the Tonsina ultramafic-mafic assemblage, Tonsina, Alaska. J. Geophys. Res. 94-B, 4373-4391.

Deer, W.A., Howie, R.A., Zussman, J., 1966. An introduction to the rock-forming minerals. Longman, London, p. 528.

Depaolo, D.J., 1981. A neodymium and strontium isotopic study of the Mesozoic calc alkaline granitic batholits of the Sierra Nevada and Peninsular Ranges, California. J. Geophys. Res. 86, 10470-10488.

Deschamps, F., Godard, M., Guillot, S., Hattori, K., 2013. Geochemistry of subduction zone serpentinites: a review. Lithos 178, 96-127.

Dijkstra, A.H., Brouwer, F.M., Cunningham, W.D., Buchan, C., Badarch, G., Mason, P.R D., 2006. Late Neoproterozoic proto-arc ocean crust in the Dariv Range, Western Mongolia: a supra-subduction zone end-member ophiolite. J. Geol. Soc. London 163, 363-373.

Dilek, Y., 2003. Ophiolite concept and its evolution. In: Dilek, Y., Newcomb, S. (Eds.), Ophiolite Concept and the Evolution of Geological Thought: Geological Society of America Bulletin, Special Publication, vol. 373, pp. 1-16.

Dilek, Y., Robinson, P.T. (Eds.), 2003. Ophiolites in Earth History, Special Publications. Geological Society, London, p. 700.

Eugster, H.P., Wones, D.R., 1962. Stability relations of the ferruginous biotite, annite. J. Petrol. 3, 82-125.

Eyuboglu, Y., Dilek, Y., Bozkurt, E., Bektas, O., Rojay, B., Sen, C., 2010. Structure and geochemistry of an Alaskan-type ultramafic-mafic complex in the Eastern Pontides, NE Turkey. Gondwana Res. 18 (1), 230-252.

Eyuboglu, Y., Santosh, M., Bektas, O., Chung, S.-L., 2011. Late Triassic subductionrelated ultramafic-mafic magmatism in the Amasya region (eastern Pontides, N. Turkey): implications for the ophiolite conundrum in Eastern Mediterranean. J. Asian Earth Sci. 42 (3), 234-257.

Farahat, E.S., Helmy, H.M., 2006. Abu Hamamid Neoproterozoic Alaskan-type complex, south Eastern Desert, Egypt. J. Afr. Earth Sci. 45, 187-197.

Ferreira, V.P., Sial, A.N., Jardim de Sá, E.F., 1998. Geochemical and isotopic signatures of Proterozoic Granitoids in terranes of the Borborema structural province northeast Brazil. J. S. Am. Earth Sci. 11 (5), 438-455.

Force, E.R., 1991. Geology of Titanium-Mineral Deposits, vol. 259. Geological Society of American, p. 121, Special paper.

Franz, L., Wirth, R., 2000. Spinel inclusions in olivine of peridotite xenoliths from TUBAF seamount (Bismarck Archipelago/Papua New Guinea): evidence for the thermal and tectonic evolution of the oceanic lithosphere. Contrib. Mineral. Petrol. 140, 283-295.

Gao, J.F., Zhou, M.F., Lightfoot, P.C., Wang, C.Y., Qi, L., 2012. Origin of PGE-poor and Cu-rich magmatic sulfides from the Kalatongke deposit, Xinjiang, Northwest China. Econ. Geol. 107, 481-506.

Garuti, G., 2011. Global Tectonics and Chromite-Platinum Mineralization Monitoring Genesis and Evolution of Ural-Alaskan type Complexes. Revista de la sociedade española de mineralogía 15, 15-16.

Gass, L.G., 1968. Is the Troodos massif of Cyprus a fragment of Mesozoic ocean floor? Nature 221, 926-930.

Gass, I.G., 1980. The Troodos massif: its role in the unravelling of the ophiolite problem and its significance in the understanding of constructive plate margin process. In: Panayistou, A. (Ed.), Ophiolites. Geological Survey of Cyprus, pp. 23-35.

Gióia, S.M.C.L, Pimentel, M.M. 2000. The Sm-Nd isotopic method in the geocrhronology laboratory of the University of Brasilia. An. Acad. Bras. Ciênc. $72,219-245$

Gomes, H.A., Santos, E.J., 2001. Mapa Geológico do estado de Pernambuco. E: 1:500.000. CPRM/Serviço Geológico do Brasil, Recife.

Green, T.H., Pearson, N.J., 1987. An experimental study of Nb and Ta partitioning between Ti-rich minerals and silicate liquids at high pressure and temperature. Geochim. Cosmochim. Acta 51, 55-62.

Grütter, H.S., Gurney, J.J., Menzies, A.H., Winter, F., 2004. An updated classification scheme for mantle-derived garnet, for use by diamond explorers. Lithos 77 $841-857$.

Guimarães, I.P., Silva Filho, A.F., Almeida, C.N., Van Schmus, W.R., Araújo, J.M.M., Melo, S.C., Melo, E.B., 2004. Brasiliano (Pan-African) granitic magmatism in the Pajeú-Paraíba belt, Northeast Brazil: an isotopic and geochronological approach. Precambrian Res. 135, 23-53.

Guimarães, I.P., Van Schmus, W.R., Brito Neves, B.B., Bittar, S.M., Silva Filho, A.F., Armstrong, R., 2012. U Pb zircon ages of orthogneisses and supracrustal rocks of the Cariris Velhos belt: onset of Neoproterozoic rifting in the Borborema Province, NE Brazil. Precambrian Res. 192-195, 52-77.

Guimarães, I.P., de Fatima L. de Brito, M., Lages, G. de A., da Silva Filho, A.F., Santos, L., Brasilino, R.G., 2015. Tonian granitic magmatism of the Borborema Province, NE Brazil: a review. J. S. Am. Earth Sci. http://dx.doi.org/10.1016/j. jsames.2015.10.009.

Hart, S.R., 1988. Heterogeneous mantle domains: signature, genesis and mixing chronologies. Earth Planet. Sci. Lett. 90, 273-296.
Hattori, K.H., Guillot, S., Saumur, B.-M., Tubrett, M.N., Vidal, O., Morfin, S., 2010. Corundum-bearing garnet peridotite from northern Dominican Republic: a metamorphic product of an arc cumulate in the Caribbean subduction zone. Lithos 114, 437-450.

Hawkesworth, C.J., Hergt, J.M., McDermott, F., Ellam, R.M., 1991. Destructive margin magmatism and the contributions from the mantle wedge and subducted crust. Aust. J. Earth Sci. 38, 577-594.

Helmy, H.M., El Mahallawi, M.M., 2003. Gabro Akarem mafic-ultramafic complex, Eastern Desert, Egypt: a late Precambrian analogue of Alaskan-type complexes. Mineral. Petrol. 77 (1-2), 85-108.

Helmy, H.M., El-Rahman, Y.M.A., Yoshikawa, M., Shibata, T., Arai, S., Tamura, A., Kagami, H. 2014. Petrology and Sm-Nd dating of the Genina Gharbia Alaskantype complex (Egypt): insights into deep levels of Neoproterozoic island arcs. Lithos. http://dx.doi.org/10.1016/j.lithos.2014.03.028.

Helz, R.T., 1973. Phase relations of basalts in the melting range at $\mathrm{PH}_{2} \mathrm{O}=5 \mathrm{~kb}$ as a function of oxygen fugacity. J. Petrol. 14, 249-302.

Himmelberg, G.R., Loney, R.A., 1995. Characteristics and Petrogenesis of Alaskantype Ultramafic-Mafic Intrusions, Southeastern Alaska. Professional Paper 1564. U.S Geological Survey, p. 43.

Hofmann, A.W., 1988. Chemical differentiation of the Earth: the relationship between mantle, continental crust, and oceanic crust. Earth Planet. Sci. Lett. 90 (3), 297-314.

Hou, T., Zhang, Z., Encarnacion, J., Santosh, M., 2012. Petrogenesis and Metallogenesis of the Taihe Gabbroic Intrusion Associated with Fe-Ti-Oxide Ores in the Panxi District, Emeishan Large Igneous Province, Southwest China. Ore Geol. Rev. 49, 109-127.

Irvine, T.N., 1974. Petrology of the Duke Island Ultramafic Complex Southeastern Alaska. Geological Society of American, p. 244.

Ishiwatari, A., Ichiyama, Y., 2004. Alaskan-type plutons and ultramafic lavas in Far East Russia, Northeast China and Japan. Int. Geol. Rev. 46, 316-331.

Jahn, B., Caby, R., Monie, P., 2001. The oldest UHP eclogites of the World: age of UHP metamorphism, nature of protoliths and tectonic implications. Chem. Geol. 178, 143-158.

Jan, M.Q., Windley, B.F., 1990. Chromium-spinel silicate chemistry in ultramafic rocks of the Jijal complex. Northwestern Pakistan. J. Petrol. 31, $667-715$.

Janoušek, V., Farrow, C.M., Erban, V., 2006. Interpretation of whole-rock geochemical data in igneous geochemistry: introducing Geochemical Data Toolkit (GCDkit). J. Petrol. 47 (6), 1255-1259.

Jardim de Sá, E.F., 1994. A Faixa Seridó (Província Borborema, NE do Brasil) e o seu significado geodinâmico na cadeia Brasiliana/Pan-Africana. Tese de Doutorado, IGc - Universidade de Brasília, Brasília-DF, p. 804.

Jardim de Sá, E.F., Macedo, M.H.E., Fuck, R.A., Kawashita, K., 1992. Terrenos proterozóicos na Província Borborema e a margem norte do Cráton São Francisco. Rev. Bras. Geociênc. 22 (4), 472-480.

Johan, Z., 2002. Alaskan-type complexes and their platinum-group element mineralization. In: Cabri, L.J. (Ed.), Geology, Geochemistry, Mineralogy and Mineral Beneficiation of Platinum-Group Elements. Canadian Institute of Mining, Metallurgy and Petroleum, pp. 669-719.

Kelemen, P.B., Hanghoj, K., Greene, A.R., 2003. One view of the Geochemistry of Subduction-related magmatic Arcs, with an emphasis on Primitive Andesite and Lower Crust. Treatise on Geochemistry, pp. 594-649.

Kozuch, M., 2003. Isotopic and trace element geochemistry of early neoproterozoic gneissic and metavolcanic rocks in the Cariris Velhos orogen of the Borborema Province, Brazil, and their bearing on tectonic setting. Tese (Doutorado) Department of Geology, University of Kansas, Kansas, p. 199.

Krause, J., Brügmann, G.E., Pushkarev, E.V., 2007. Accessory and rock forming minerals monitoring the evolution of zoned mafic-ultramafic complexes in the Central Ural Mountains. Lithos 95 (1-2), 19-42.

Kusky, T.M., Glass, A., Thcker, R., 2007. Structure, Cr-chemistry, and age of the Border Ranges Ultramafic-Mafic Complex: a suprasubduction zone ophiolite complex. Geol. Soc. Am. Spec. Pap 431, 207-225.

Lages, G.A., Dantas, E.L., Santos, L.C.M., 2014. Sítio do Icó Orthogneiss, east of Transversal Zone, Borborema Province. Stenian Orthogneiss with Juvenile caractheristics. In: 9th South American Symposium on Isotope Geology, p. 113. Abstract.

Le Bas, M.J., 1962. The role of aluminum in igneous clinopyroxenes with relation to their parentage. Am. J. Sci. 260, 267-288.

Leake, B.E., Woolley, A.R., Arps, C.E.S., Gilbert, M.C., Grice, J.D., Hawthorne, F.C., Whittaker, E.J.W., 1997. Nomenclature of Amphiboles. The Canadian Mineralogist 35, 219-246.

Leake, B.E., Woolley, A.R., Birch, W.D, Burke, E.A.J., Ferraris, G., Grice, J.D. Hawthorne, F.C., Whittaker, E.J.W., 2004. Nomenclature of amphiboles: additions and revisions to the international association's amphibole nomenclature. Am. Mineral. 89, 883-887.

Lepage, L.D., 2003. ILMAT: an excel worksheet for ilmenite-magnetite geothermometry and geobarometry. Comput. Geosci. 29, 673-678.

Leterrier, J., Maury, R.C., Thonon, P., Girard, D., Marchal, M., 1982. Clinopyroxene composition as a method of identification of the magmatic affinities of paleovolcanic series. Earth Planet. Sci. Lett. 59, 139-154.

Loucks, R.R., 1990. Discrimination of ophiolitic from nonophiolitic ultramafic-mafic allochthons in orogenic belts by the $\mathrm{Al} / \mathrm{Ti}$ ratio in clinopyroxene. Geology 18, 346-349.

Ludwig, K.R., 1993. PBDAT. A computer program for processing $\mathrm{Pb}-\mathrm{U}-\mathrm{Th}$ isotope data. In: USGS Open File Report, 88-542, p. 34. 
Ludwig, K.R., 2001. Useŕs Manual for Isoplot/Ex version 2.47. A geochronological toolkit for Microsoft Excel, vol. 1a. Berkeley Geochronology Center Special Publication, p. 55.

McDonough, W.F., Sun, S.S., 1995. The composition of the Earth. Chem. Geol. 120, 223-253.

Medeiros, V.C., 2004. Evolução geodinâmica e condicionamento estrutural dos terrenos Piancó- Alto Brígida e Alto Pajeú, Domínio da Zona Transversal, NE do Brasil. In: Tese de Doutorado, Programa de Pós-Graduação em Geodinâmica e Geofísica, Universidade Federal do Rio Grande do Norte, pp. 200.

Medeiros, V.C., Jardim de Sá, E.F., Macedo, M.H.F., Souza, Z.S., 1993. Estruturas Tangenciais e Metagranitóides Transamazônicos na Faixa SalgueiroCachoeirinha a Oeste de Parnamirm-PE. In: XV Simpósio de Geologia do Nordeste. Sociedade Brasileira de Geologia (SBG), Natal, pp. 284-287.

Moores, E.M., 1982. Origin and emplacement of ophiolites. Rev. Geophys. 20, 735760.

Moraes, J.F.S., 1992. Petrologia das máficas e ultramáficas da sequencia vulcanosedimentar de Monte Orebe, PE/PI (Dissertação de mestrado). UFBA, p. 98.

Morimoto, N., 1988. Nomenclature of pyroxenes. Mineral. Petrol. 39, 55-76.

Murray, C.G., 1972. Zoned ultramafic complexes of the Alaskan type: feeder pipes of andesitic volcanoes. In: Shagam, R. et al. (Eds.), Studies in Earth and Space Sciences: Geological Society of America. Memoir, vol. 132, pp. 313-335.

Nascimento, M.A.L., Antunes, A.F., Galindo, A.C., Jardim de Sá, E.F., de Souza, Z.S., 2000. Geochemical Signature of the Brasiliano-Age Plutonism in the Seridó Belt, Northeastern Borborema Province (NE Brazil). Rev. Bras. Geociênc. 30 (1), 161164

Nascimento, M.A.L., Medeiros, V.C. Galindo, A.C., 2008. Magmatismo Ediacarano no Domínio Rio Grande do Norte, Província Borborema, NE do Brasil. In: Estudos Geológicos, vol. 18. UFPE, pp. 4-25 (1)

Neves, S.P., 2003. Proterozoic history of the Borborema Province (NE Brazil): correlations with neighboring cratons and Pan-African belts, and implications for the evolution of western Gondwana. Tectonics 22, 1031. http://dx.doi.org/ $10.1029 / 2001$ TC001352.

Neves, S.P., Mariano, G., Guimarães, I.P., Silva Filho, A.F., Melo, S.C., 2000. Intralithospheric differentiation and crustal growth: evidence from the Borborema Province, Northeastern Brazil. Geology 28 (6), 519-522.

Oliveira, R.G., 2008. Arcabouço geofísico, isostasia e causas do magmatismo cenozóico da Província Borborema e de sua margem continental (Nordeste do Brasil). Natal, 411 p. Tese (Doutorado) - Programa de Pós-graduação em Geodinâmica e Geofísica, UFRN.

Oliveira, E.P., Windley, B.F., Araújo, M.N.C., 2010. The Neoproterozoic Sergipano orogenic belt, NE Brazil: A complete plate tectonic cycle in western Gondwana. Precambrian Res. 181, 64-84.

Pearce, J.A., 1975. Basalt geochemistry used to investigate past tectonic environments on Cyprus. Tectonophysics 25, 41-67.

Pearce, J.A., 1982. Trace element characteristics of lavas from destructive plate boundaries. In: Thorpe, R.S. (Ed.), Andesites. Wiley, Chichester, pp. 525-548.

Pearce, J.A., 2008. Geochemical fingerprinting of oceanic basalts with applications to ophiolite classification and the search for Archean oceanic crust. Lithos 100, 1448.

Pearce, J.A., Robinson, P.T., 2010. The Troodos ophiolitic complex probably formed in a subduction initiation, slab edge setting. Gondwana Res. 18, 60-81.

Pearce, J.A., Lippard, S.J., Roberts, S., 1984. Characteristics and tectonic significance of supra-subductionzoneophiolites. In: Kokelaar, B.P., Howells, M.F. (Eds.) Marginal Basin Geology: Geological Society of London, Special Publication, vol. 16, pp. 77-89.

Pettigrew, N.T., Hattori, K.H., 2006. The Quetico Intrusions of Western Superior Province: Neo-Archean examples of Alaskan/Ural-type mafic-ultramafic intrusions. Precambrian Res. 149 (1-2), 21-42.

Ringwood, A.E., 1990. Slab-mantle interactions: 3. Petrogenesis of intraplate magmas and structure of the upper mantle. Chem. Geol. 82, 187-207.

Ripley, E.M., 2009. Magmatic sulfide mineralization in Alaskan-type complexes. In: Li, C.S., Ripley, E.M. (Eds.), New Developments in Magmatic Ni-Cu and PGE Deposits, pp. 219-228.

Rollinson, H.R., 1993. Using Geochemical Data: Evaluation, Presentation, Interpretation. Longman Geochemistry Society, London, p. 352.

Rublee, V.J., 1994. Chemical petrology, mineralogy and structure of the Tulameen Complex, Princeton area, British Colombia (M.Sc. thesis). University of Ottawa, Canada, p. 179.

Salem, A.K.A., Khalil, A.E., Ramadan, T.M., 2012. Geology, geochemistry and tectonic setting of Pan-African serpentinites of Um Salim-Um Salatit area, Central Eastern Desert, Egypt. Egypt. J. Remote Sens. Space Sci. 15, 171-184.

Sales, A.O., dos Santos, E.J., Lima, E.S., Santos, L.C.M.D.L., de Brito Neves, B.B., 2011 Evolução Petrogenética e Tectônica do Evento Cariris Velhos na Região de Afogados da Ingazeira (PE), Terreno Alto Pajeú, Província Borborema. Geol. USP. Série Científica 11, 101-121.

Santos, E.J. dos., 1995. O complexo granítico Lagoa das Pedras: acresção e colisão na Região de Floresta (Pernambuco), Província Borborema. Sao Paulo. In: Tese (Doutorado em Geociências, Área de Concentração Geoquímica Geotectônica) Universidade de São Paulo. Instituto de Geociências, pp. 220.

Santos, E.J., Brito Neves, B.B., 1984. Província Borborema. In: Almeida, F.F.M., Hasui, T. (Eds.), O Pré-Cambriano do Brasil. Edgar Blucher, São Paulo, pp. 123-186.

Santos, E.J., Medeiros, V.C., 1999. Constraints from granitic plutonism on Proterozoic crustal grownth of the Zona Transversal Domain, Borborema Province, NE Brazil. Rev. Bras. Geociênc. 29, 73-84.
Santos, E.J., Van Schmus, W.R., Brito Neves, B.B., Oliveira, R.G., Medeiros, V.C., 1999 Terrane and their boundaries in the Proterozoic Borborema Province, Northeast Brazil. In: Anais do VII Simpósio Nacional de Estudos Tectônicos (SNET). Resumos expandidos, pp. 121-124.

Santos, E.J., Van Schmus, W.R., Kozuch, M., de Brito Neves, B.B., 2010. The Cariris Velhos tectonic event in Northeast Brazil. J. South Am. Eath Sci. 29, 61-76.

Santos, T.J.S., Amaral, W.S., Ancelmi, M.F., Pitarello, M.Z., Fuck, R.A., Dantas, E.L. 2014a. U-Pb age of the coesite-bearing eclogite from NW Borborema Province. Implications for western Gondwana assembly, Gondwana Research, NE Brazil. http://dx.doi.org/10.1016/j.gr.2014.09.013.

Santos, E.J., Lira Santos, L.C.M., Guimarães, I.P., Armstrong, R., 2014b. New age and tectonic constraints of the Riacho do Icó Suite, Alto Pajeú Terrane, Borborema Province based on Sm-Nd and U-Pb SHRIMP systematics. In: 9th South American Symposium on Isotope Geology. Boletim de Resumos. USP, São Paulo, p. 159.

Seo, J., Oh, C.W., Choi, S.G., Rajesh, V.J., 2013. Two ultramafic rock types in the Hongseong area, South Korea: Tectonic significance for northeast Asia. Lithos 175-176, 30-39.

Shaw, J.E., Baker, J.A., Menzies, M.A., Thirlwall, M.F., Ibrahim, K.M., 2003. Petrogenesis of the largest intraplate volcanic field on the Arabian plate (Jordan): a mixing lithosphere-asthenosphere source activated by lithospheric extension. J. Petrol. 44, 1657-1679.

Shervais, J.W., 1982. Ti-V plots and the petrogenesis of modern and ophiolitic lavas. Earth Planet. Sci. Lett. 59, 101-118.

Sisson, T.W., Grove, T.L., 1993. Experimental investigations of the role of $\mathrm{H}_{2} \mathrm{O}$ in calc-alkaline differentiation and subduction zone magmatism. Contrib. Mineral. Petrol. 113, 143-166.

Song, X.Y., Xie, W., Deng, Y.F., Crawford, A.J., Zheng, W.Q., Zhou, G.F., Deng, G. Cheng, S.L., Li, J., 2011. Slab break-off and the formation of Permian maficultramafic intrusions in southern margin of Central Asian Orogenic Belt, Xinjiang, NW China. Lithos 127, 128-143.

Spandler, C., Hermann, J., Arculus, R., Mavrogenes, J., 2003. Redistribution of trace elements during prograde metamorphism from lawsonite blueschist to eclogite facies; implications for deep subduction-zone processes. Contrib. Mineral. Petrol. 146, 205-222.

Stormer Jr., J.C., 1983. The effects of recalculation on estimates of temperature and oxygen fugacity from analyses of multicomponent iron-titanium oxides. Am. Mineral. 68, 586-589.

Su, B., Qin, K., Sakyi, P.A., Malaviarachchi, S.P.K., Liu, P., Tang, D., Xiao, Q.-H., Sun, H., Ma, Y.-G., Mao, Q., 2012. Occurrence of an Alaskan-type complex in the Middle Tianshan Massif, Central Asian Orogenic Belt: inferences from petrological and mineralogical studies. Int. Geol. Rev. 54, 37-41.

Su, B.-X., Qin, K.-Z., Santosh, M., Sun, H., Tang, D.-M., 2013. The Early Permian maficultramafic complexes in the Beishan Terrane, NW China: Alaskan-type intrusives or rift cumulates? J. Asian Earth Sci. 66, 175-187.

Su, B.-X., Qin, K.-Z., Zhou, M.-F., Sakyi, P.A., Thakurta, J., Tang, D.-M., Liu, P.-P., Xiao, Q.-H., Sun, H., 2014. Petrological, geochemical and geochronological constraints on the origin of the Xiadong Ural-Alaskan type complex in NW China and tectonic implication for the evolution of southern Central Asian Orogenic Belt Lithos 200-201, 226-240.

Sun, S.S., McDonough, W.F., 1989. Chemical and isotopic systematics of oceanic basalts: implications for mantle composition and processes. Geol. Soc. London Spec. Publ. 42 (1), 313-345.

Taylor Jr., H.P., 1967. The zoned ultramafic complexes of the Southeastern Alaska, Part 4. III. In: Wyllie, P.J. (Ed.), Ultramafic and Related Rocks. John Willey, New York, pp. 96-118.

Thakurta, J., Ripley, E.M., Li, C.S., 2008. Geochemical constraints on the origin of sulfide mineralization in the Duke Island complex, southeastern Alaska. Geochem. Geophys. Geosyst., Q07003

Thanh, N.X., Hai, T.T., Hoang, N., Lan, V.Q., Kwon, S., Itaya, T., Santosh, M., 2014 Backarc mafic-ultramafic magmatism in Northeastern Vietnam and its regional tectonic significance. J. Asian Earth Sci. 90, 45-60.

Tian, W., Chen, B., Ireland, T.R., Green, D.H., Suzuki, K., Chu, Z., 2011. Petrology and geochemistry of dunites, chromitites and mineral inclusions from the Gaositai Alaskan-type complex, North China Craton: implications for mantle source characteristics. Lithos 127, 165-175.

Tindle, A.G., Webb, P.C., 1994. Probe-AMPH-a spreadsheet program to classify microprobe-derived amphibole analyses. Comput. Geosci. 20, 1201-1228.

Van Schmus, W.R., de Brito Neves, B.B., Hackspacher, P., Babinski, M., 1995. U/Pb and $\mathrm{Sm} / \mathrm{Nd}$ geochronologic studies of the eastern Borborema Province, northeastern Brazil: initial conclusions. J. South Am. Earth Sci. 8, 267-288.

Van Schmus, W.R., Oliveira, E.P., Silva Filho, A.F., Toteu, S.F., Penaye, J., Guimarães, I. P., 2008. Proterozoic links between the Borborema Province, NE Brazil, and the Central African Fold Belt. Geol. Soc. London Spec. Publ. 294, 66-69.

Van Schmus, W.R., Kozuch, M., de Brito Neves, B.B., 2011. Precambrian history of the Zona Transversal of the Borborema Province, NE Brazil: Insights from Sm-Nd and U-Pb geochronology. J. S. Am. Earth Sci. 31 (2-3), 227-252.

Vauchez, A., Neves, S.P., Caby, R., Corsini, M., Egidio-Silva, M., Arthaud, M., Amaro V., 1995. The Borborema shear zone system, NE Brazil. J. S. Am. Earth Sci. 8, 247-266.

Wang, Z., Wilde, S.A., Wan, J., 2010. Tectonic setting and significance of 2.3-2.1 Ga magmatic events in the Trans-North China Orogen: New constraints from the Yanmenguan mafic-ultramafic intrusion in the Hengshan-Wutai-Fuping area. Precambrian Res. 178, 27-42. 
White, W.M., Duncan, R.A., 1996. Geochemistry and geochronology of the Society Island: new evidence from deep mantle recycling. In: Basu, A., Hart, S.R. (Eds.), Earth Processes: Reading the Isotopic Code: Geophysical Monograph, 95. AGU, Washington, DC, pp. 183-206.

Wilson, M., 1989. Igneous Petrogenesis - A Global Tectonic Aproach. Springer, p. 466.

Xie, Z., Hattori, K., Wang, J., 2013. Origins of ultramafic rocks in the Sulu Ultrahighpressure Terrane, Eastern China. Lithos 178, 158-170.

Xie, W., Song, X.-Y., Chen, L.-M., Deng, Y.-F., Zheng, W.-Q., Wang, Y.-S., Ba, D.-H., Yin, M.-H., Luan, Y., 2014. Geochemistry insights on the genesis of the subductionrelated Heishan magmatic Ni-Cu-(PGE) deposit, Gansu, Northwestern China, at the Southern Margin of the Central Asian Orogenic Belt. Econ. Geol. 109, 1563 1583.

Xiong, X.L., 2006. Trace element evidence for growth of early continental crust by melting of rutile-bearing hydrous eclogite. Geology 34, 945-948.

Yavuz, F., 2013. WinPyrox: a Windows program for pyroxene calculation classification and thermobarometry. Am. Mineral. 98, 1338-1359.

Yellappa, T., Venkatasivappa, V., Koizumi, T., Chetty, T.R.K., Santosh, M., Tsunogae, T., 2014. The mafic-ultramafic complex of Aniyapuram, Cauvery Suture Zone,
Southern India: Petrological and geochemical constraints for Neoarchean suprasubduction zone tectonics. J. Asian Earth Sci. http://dx.doi.org/10.1016/j. jseaes.2014.04.023.

Zaccarini, F., Pushkarev, E., Garuti, G., 2008. Platinum-group element mineralogy and geochemistry of chromitite of the Kluchevskoy ophiolite complex, central Urals (Russia). Ore Geol. Rev. 33, 20-30.

Zhang, Z.C., Mao, J.W., Chai, F.M., Yan, S.H., Chen, B.L., Pirajno, F., 2009. Geochemistry of the Permian Kalatongke mafic intrusions, Northern Xinjiang, Northwest China: implications for the genesis of magmatic $\mathrm{Ni}-\mathrm{Cu}$ sulfide deposits. Econ. Geol. 104, 185-203.

Zhang, M., Li, C., Fu, P., Hu, P., Ripley, E.M., 2011. The Permian Huangshanxi Cu-Ni deposit in western China: intrusive-extrusive association, ore genesis and exploration implications. Mineral. Deposita 46, 153-170.

Zimmer, M., Kroner, A., Jochum, K.P., Reischmann, T., Todt, W., 1995. The Gabal Gerf complex: a Precambrian N-MORB ophiolite in the Nubian Shield, NE Africa. Chem. Geol. 123, 29-51.

Zindler, A., Hart, S., 1986. Helium: problematic primordial signals. Earth Planet. Sci. Lett. $79,1-8$. 